\title{
PrivatiZATION IN Austria: SOME THEORETICAL REASONS AND FIRST RESULTS ABOUT THE PRIVATIZATION PROCEEDS
}

\author{
ANSGAR BELKE \\ FRIEDRICH SCHNEIDER
}

CESIFO WORKING PAPER NO. 1123

CATEgORy 2: Public CHOICE

JANUARY 2004

Presented at Cesifo CONFERENCE ON PRIVATISATION EXPERIENCES IN THE EU NOVEMBER 2003

\footnotetext{
An electronic version of the paper may be downloaded

- from the SSRN website:

- from the CESifo website:

www.SSRN.com

www.CESifo.de
} 


\title{
PRIVATIZATION IN AUSTRIA: SOME THEORETICAL REASONS AND FIRST RESULTS ABOUT THE PRIVATIZATION PROCEEDS
}

\begin{abstract}
The issues of privatization (and sometimes deregulation) have been reviewed in a large literature on the various aspects of privatization, that has emphasized the potential efficiency gains. Hence, the goal of this paper is twofold: First to provide some theoretical reasoning why privatization is useful as well as profitable for an economy and second to empirically present the extent of privatization in Austria and other European Union countries. Therefore, the reasons why privatization is necessary are elaborated. Then the specific pattern privatization proceeds for Austria relative to other EU and OECD countries is presented. Moreover, some important idiosyncratic extensions for the Austrian case are elaborated. We argue that in the Austrian case, any discussion of privatization cannot be reduced to observing cash flows, the employment performance and the stock-exchange ratings of the privatized formerly stateowned enterprises. Since polito-economic aspects relating to income distribution and ideology play an important role in explaining the way, the extent, the speed and the economic effects of privatization, they have to be considered as well.
\end{abstract}

JEL Classification: H42, E62, L33.

Keywords: Austria, partisan approach, privatization, state-owned enterprises, public choice.

\author{
Ansgar Belke \\ Department of Economics \\ University of Hohenheim \\ 70599 Stuttgart \\ Germany \\ belke@uni-hohenheim.de
}

\author{
Friedrich Schneider \\ Department of Economics \\ Johannes Kepler University of Linz \\ Altenbergerstrasse 69 \\ A-4040 Linz-Auhof \\ Austria \\ friedrich.schneider@jku.at
}

Revised paper prepared for the conference "Privatization Experiences in the EU -Part II", November 1-2, 2003, CESifo, Villa La Collina, Cadenabbia/Italy. We are grateful for valuable comments to an anonymous referee and to Rainer Fehn, Andreas Freytag, Eduard Hochreiter, Marko Koethenbuerger, Hans-Werner Sinn, and John Whalley. 


\section{Introduction}

Privatization has been a key element of structural policy reforms in most European Union countries including Austria during the last decade. Governments undertaking privatization have pursued a variety of objectives: achieving gains in economic efficiency, given the extensive prevalence of poor economic performance of public enterprises in many countries and limited success with their reform; and improving the fiscal position, particularly in cases where governments have been unwilling or unable to continue to finance deficits in the public enterprise sector. In addition, budgetary-constrained governments, facing fiscal pressures have sometimes privatized mainly for the reason to finance fiscal deficits with the privatization proceeds.

The issues of privatization (and sometimes deregulation) have been reviewed in a large literature on the various aspects of privatization, that has emphasized the potential efficiency gains. ${ }^{1}$ Hence, the goal of this paper is twofold: First to provide some theoretical reasoning why privatization is useful as well as profitable for an economy and second to empirically present the extent of privatization in Austria and other European Union countries. Therefore, in section 2 , the reasons why privatization is necessary are elaborated. Then, in part 3, the specific pattern privatization proceeds for Austria relative to other EU and OECD countries is presented. Section 4 elaborates on some idiosyncratic extensions for the Austrian case. Finally, in part 5, a short summary of these findings and some policy conclusions are given. In the 
Austrian case, any discussion of privatization cannot be reduced to observing cash flows, the employment performance and the stock-exchange ratings of the privatized formerly state-owned enterprises (SOEs). Polito-economic aspects relating to income distribution and ideology play an important role in explaining the way, the extent, the speed and the economic effects of privatization and have to be considered as well.

\section{Reasons for Privatizing Public Enterprises}

For at least the last century, economists have employed a positive economic theory to explore the implications of profit maximization by private firms operating in private property contexts. Only since the late 1960's have empirical studies been undertaken dealing with the behavior of publicly operated firms. ${ }^{2}$ Since then a large number of studies of a variety of activities of public or private enterprises now exists and their main focus is the question of how public firms differ from their private equivalents.

Basically two approaches are employed. The first, explored in part 2.1, is the property rights approach. It concentrates on the differences in the ease of captureability of economic surplus of a resource and the rights to direct an asset's use, alter its from or transfer its claims among existent and potential owners. In short, this approach explores the differences in incentives between public and private agencies caused by variation in the ability of owners to monitor management and the problems that emerge when the goals of "owners" and their agents, "managers", diverge." The second one is called 
"Public Choice approach" (elaborated in part 2.2) and concentrates on political coalitions and their effect on input usage and reward and/or product characteristics. The Public Choice approach also includes the theory of bureaucracy (Niskanen, 1971, 1975).

\subsection{The Property Rights Approach}

The property rights approach points out one crucial difference between private and public firms. The practical difficulties in transferring ownership rights among individuals in the public sector and the relative ease of such transactions with private assets which includes, of course, the ability of owners (citizens) to monitor their agents (elected officials' and bureaucrats') behaviour. Up to now, this approach pioneered by Armen Alchian is well known, but it is useful to recall his predictions: government managers will not organize the inputs under their direction in such a way, as to maximize the wealth of the tentative owners, the general citizenry. Alchian predicts, therefore, that public firms will be less efficient, their management will enjoy "quieter lives" and because of this the public will give them lower levels of discretion then their colleagues in private firms. To put it in another way, the property rights approach is concerned with any type of cooperation in which ownership and management fall apart. The arising principal-agent problem may be virulent in private enterprises as well, but to a much lesser extent! Numerous studies have been undertaken, which have tested this proposition and the results that public enterprises are less efficient then private ones, is confirmed in most of them. ${ }^{4)}$ 
To sum up the results so far: the property rights approach seems to indicate that (1) private production is cheaper than production in publicly owned and managed firms and (2) given sufficient competition between public and private producers (and no discriminative regulations and subsidies) the differences in unit cost turn out to be insignificant. From this, one may conclude that it is not so much the difference in the transferability of ownership but the lack of competition which leads to the often observed and less efficient production in public enterprises.

\subsection{The Public Choice Approach}

The public choice approach appears to provide a broader analysis than the property rights one. The public choice approach assumes that politicians, bureaucrats, managers of public enterprises are selfish utility maximizers subject to constraints. ${ }^{5)}$ In this approach it is, f.e. for a politician, assumed that he acts selfish in order to reach his ideological or personal goals under the constraint not to loose the next election. As for a politician to stay in power is the most important constraint (or even sometimes a goal), he will also use public utilities for his own selfish goals. One reason for this is evidently the lack of incentives for politicians and tax payers to exert effective control of an efficient use of public enterprises or resources in the economy. This argument seems especially valid for the case of public utilities or enterprises. Public utilities offer excellent opportunities to reach the selfish re-election goals of governments like an additional employment and the stabilization of purchasing 
power of certain regions. ${ }^{6}$ ) If such a "misuse" of public utilities or enterprises leads to full employment and higher income at least for a certain time span than it is easier for a government to win an election without such a "misuse" of public utilities. The costs of such popular policies can be made invisible for several years (or even 1 or 2 legislative periods) as the deficits of the public enterprises can be hidden in the general budget deficit.

As the public choice approach is more concerned with micro-economic aspects, De Alessi claims that public managers are growth and not wealth orientated. He argues and finds supporting evidence that this leads to larger staffs and higher capital labor ratios since excess capital makes managers and their are subordinates' productivity appear higher to their monitoring agents, the legislature. Already Borcherding, Busch and Spann (1977) argue that public employees effectively coalesce through their organizations and "capture" civil service commissions over time, altering rules in such a way that effective suppliers competing labor to public firms becomes less wage elastic than a free market buyer would otherwise face. This public employee market power is enhanced, they claim, by the fact that public service employees contribute to the election of the ultimate "bosses", definitely not an option for a private sector union. In some sense then, public employees can alter the position of the derived demand schedule for their services by (a) "nudging" the final demand schedule for public services to the right and (b) specifying rules which lower both the elasticity of substitution between themselves and rival factors and the elasticity of supply of these close substitutes. Both (a) and (b) 
will tend to raise wages, but they may raise employment too, since, in effect, the budget and tie-in effects may offset the usual substitution effects one might derive from the neoclassical models of labor demand in the presence of a simple monopoly. De Alessi (1974) in another paper argues that given the relative loose monitoring of public enterprises by the political review authorities, a rational position for the latter given the gain-sharing results of assiduous monitoring, managers will indulge their taste for security rather more than in private firms. He finds evidence consistent with the risk-avoiding hypothesis. Public managers' tenures are more secure, of a longer duration, and their fluctuations in real wages are lower than their private counterparts.

In conclusion, according to the public choice scholars, governmental agencies and firms have distinct biases leading to higher production costs, just as the property rights literature suggests, but excessive outputs as well. The latter obtains because the bureaucracy can affect demand more readily under monopoly public ownership by the strength of its members' votes and/or lobbying efforts. The absence of a civil service and the constraint on strong unions by more competitive types of supply, public or private, is thought to reduce the ability of members of such bureaucracies to offer their services to the legislature on disadvantageous terms compared to potential competitors. On the other hand, the bureaucracy is not likely to have sole "capture" rights over the bureaus, but share the ownership claims with other interests. 
To sum up this part, the public choice approach not only recognizes the differences in behavior between publicly owned and managed firms and private ones due to the limited transferability of ownership. It also considers the likely oversupply of public services due to the lack of competition in their provision and production. This oversupply is then quite often used for selfish re-election goals of politicians and can result in higher employment and higher wages in certain regions for a certain time. ${ }^{7}$

\subsection{Summary of Main Findings}

If one summarizes the two approaches one clearly comes to the result that as already said in the introduction, there are various reasons to privatize public utilities or enterprises in order to stop the misuse of such policies. Even if one strictly denies that single firms are more efficient than their public counterparts one it is generally acknowledged that private enterprises are more successful on average and in the long term, since they tend to act in a more innovative fashion and as a rule enter into foreign trade relations earlier than their public counterparts. $^{8}$ Seen on the whole, one should start from the prior that the government should not have a stake in firms (Austrian Parliament, 2000). In the next section we will investigate to what extent privatization have occurred in the European Union and in Austria. 


\section{The Amount of Privatization in the European Union and in Austria}

\subsection{Does Austria keep pace with wide privatization in OECD Countries?}

This paper mainly focuses on privatization in Austria. However, privatization has not only been relevant in the Austrian case, but has also been a key element of structural reform in many other developing and transition economies during the last decade, especially in Germany, Korea, Italy, Norway and the Czech Republic (OECD 2002, p. 44). Hence, privatization and proceeds from privatization have been substantial all over the world. Hence, the performance of Austria as a small open economy is assessed in the following with reference to the average privatization performance of other OECD countries. Since the beginning of the $80 \mathrm{~s}$, numerous privatization efforts in market oriented industrial countries, but also in transition and developing countries, have taken place. European countries appeared to be particularly involved in divestitures. Bortolotti, Fantini and Siniscalco, 2001, p. 20, document that Austria, Spain, France, Germany and Italy have implemented from 40 to 80 privatization operations during the period 1977-1999. However, Austria with its 40 operations is at the lower bound of this sample. According to Siegmund (1998), 100000 large public utilities have been privatized between 1980-1996 and more than 500,000 small and medium sized public enterprises (see Table 3.1).

- Table 3.1 about here -

These privatizations are lower bound figures as privatization of financial institutions, interstate utilities are not counted here. Considering table 3.1 one 
clearly sees that obviously the largest share of privatization has taken place in transformation countries over the period 1990-1996. In figure 3.1 the revenues from privatizations between 1990-1998 for the 15 European Union, OECD and other countries are shown. In total, privatization proceeds of 22.9 billions USD occurred in the year 1990, which rose to 153.8 millions USD in the year 1997 and for the first time they decreased to 114.5 millions USD in the year 1998. The privatization proceeds (revenues) of the 15 European Union countries were in the year 199015.7 billions USD and rose to 66.6 billions USD in the year 1997, with a decline to 58.6 billions USD in the year 1998. A detailed picture of the privatization proceeds of single countries is given in Table 3.2.

- Table 3.2 about here -

In the beginning of the 1990s a real wave of privatization began to develop. In most countries the wave peaked in the second part of the 1990s. Austria, for example, obtained proceeds from privatization in 1990/91 of only $\$ 80$ million, but in 1996/97 it reached a peak of \$3.9 billion. Germany started with proceeds of $\$ 325$ million in $1990 / 91$, but obtained $\$ 14.3$ billion in 1996/97. An exception is the United Kingdom, where in 1990/91 already a peak of privatization proceeds had been reached ( $\$ 34.7$ billion). But also the later revenues from privatization have been substantial. This might not at least be due to the „right-wing” character of the Thatcher regime and can be explained by a partisan approach to privatization, as argued later on in section 4 . 
If one considers standardized figures of privatization of state-owned enterprises as a percentage of GDP in the year 2000 (column 9 of Table 3.2), the figures presented there cover a wide range. Apart from Hungary, which was a nonmarket economy with a large state sector, it is Portugal which has reached by far the highest amount of privatization proceeds over the period, namely $20.2 \%$ of GDP in 2000. Considering some developed OECD countries, New Zealand reaches $13.9 \%$, followed by Greece with $8.8 \%$, Italy with $8.2 \%$ and Ireland with $7.2 \%$. However, the total amount of privatization in Austria over the years 1990 to 2000 as a percentage of GDP is relatively low and clearly below the average performance of the EU15.

If one looks at the highest amounts of privatization proceeds during the 1990s, Italy ranks first with $\$ 98$ billion, followed by Australia with $\$ 79$ billions, by France with $\$ 74$ billions, the United Kingdom with $\$ 64$ billion and Japan with $\$ 61$ billion. Austria is ranked at a disappointing number 15 out of 27 countries. In general, Table 3.2 clearly shows that privatization in OECD countries of the Eastern and Western type was a major issue in the 1990s, but less than average so in Austria.

A special method of privatization is through public share offerings. In Table 3.3, some additional figures for a longer time perspective and for a special privatization issue, namely privatization of state-owned enterprises through public share offerings, are given.

- Table 3.3 about here - 
Over the years 1961-2000, the largest amount of privatization of state-owned enterprises through measures like public share offerings happened in Japan with $\$ 146$ billion, followed by Great Britain with $\$ 98$ billion, by Italy with $\$ 85$ billions and France with $\$ 84$ billions. According to this very long-term criterion, Austria is only ranked seventeenth out of eighteen countries. Germany had only an amount of $\$ 46$ billions of privatization proceeds of stateowned enterprises through public-share offerings. Strikingly, Austria keeps its second last rank. Finally, the issue size per country for all privatizations and the time span 1990-1999 is displayed in the last column of Table 3.3. According to this criterion, Austria improves its performance a little bit, but still shows below-average performance. In general, Tables 3.2 and 3.3 clearly demonstrate that privatization was a major issue, especially in the 1990s. However, Austria's performance was clearly below average independent on the exact criterion.

Moreover, in Table 3.4 the number and names of enterprises, which were privatized through public share offerings over the much shorter period 19902000 are shown. Among them are mostly banks, air lines, telecom and energy plants. With respect to the number of privatizations which are not necessarily positively correlated with privatization proceeds (see section 4), Austria is ranked sixth out of eighteen countries.

- Table 3.4 about here - 
Seen on the whole, Austria has not kept pace with wide privatization in OECD countries.

\subsection{Privatization in Small Open Economies}

If one considers eleven small open economies in Europe, the results presented in Table 3.5 and in Figure 3.1 emerge.

- Table 3.5 and Figure 3.1 about here -

Table 3.5 shows that the amount of privatization was quite moderate at the beginning of the 90s with the exception of Belgium. The Belgium government privatized in the year 1993 public utilities and got proceeds of 956 millions USD, which are roughly $30 \%$ of all privatization proceeds of the small open economies in Table 3.5 and Figure 3.1. The second highest privatization proceeds in this year come from the Netherlands with 780 millions USD, followed by Portugal, which had a quite ambitious privatization program over the years 1993-1998, with privatization proceeds over 12 billions USD over the 1993-1998. A lot of well known public utilities in Portugal have been privatized like the power plant EDP, the highway system BRISA and cement factories ZINPOR. Also in Austria the privatization proceeds have been quite large. In the year 1998 in Austria the government privatized firms with proceeds of 2.94 billions USD. In Austria the selling of 25\% share of the public telecom was the biggest deal, where proceeds of 2.33 billions USD have been achieved. Starting with rank 7 in 1993, Austria improved its performance in percent of total privatization proceeds in small open economies steadily with a 
peak in 1997 and at the end of the sample ranges at number three out of eleven small open economies. However, one should not overemphasize this pattern, since also in general the amount of privatization proceeds in small open economies increased over 1993-1998. In the year 1993 it was 3.26 billions USD and in the year 199820.246 billions USD.

In Figure 3.1, the privatization proceeds of small open economies are shown in relation to GNP. One clearly realizes the dominant position of Portugal over time, followed by the Netherlands and Belgium which display enormous privatization proceeds in the years 1993 and 1995. In Austria, we have privatization proceeds in percent of GDP over the years which amount to the average of the small open economies under consideration. However, we cannot detect any systematic correlation between the degree of openness of an economy and its privatization intensity. In general, this makes external impacts on the speed and intensity less plausible of privatization. However, we will show in section 4 that this was not the case for Austria. At most, the (announcement of) the launch of the euro seems to have speeded up the privatization wave in Europe. In general, one realizes that the privatization issue and the proceeds from privatization have been a considerable and policy relevant issue in the 90s also for the small open economies.

\subsection{Privatization in Austria}

Among those industrialized countries now awaiting further privatization, Austria is a special one characterized by historically strong interventions of 
government. Large parts of the manufacturing and the electricity sector had been nationalized after world war II, in part to safeguard the country's economic independence after German occupation and in part in order to finance the resurrection of destroyed large-scale industries. Jointly with public ownership in telecommunication, transport, and banking this generated one of the largest public sectors in Europe. ${ }^{10}$ Seen on the whole, Austria's economy has been characterized by a relative important state-owned industry, a lack of own capital funds due to the comparatively small company size, and a predominantly bank-based investment system. In 1998, Austria was characterized by 17 percent market capitalization relative to GDP, i.e. an even lower valuation ratio than Italy (30 percent) and Germany (39 percent) (Boutchkova and Megginson, 2000, p. 9, Table III). The globalization and Austria's accession to the EU have revealed the structural problems of this system. Those sectors of the Austrian economy which have been protected from international competition like, above all, telecommunication, energy supply and food industries had to be integrated in the internal market. As a consequence, restructuring programs have recently been launched focusing on liberalization and privatization of Austria's economy. In addition, joining the European Union represented a structural break for Austria with respect to the incentives to delay necessary deregulation and privatization because it was now much less attractive to use public utilities and industries for re-election purposes. ${ }^{11}$ 
The Austro-Keynesian era of stabilization policy which lasted from the beginning of 70 s to the mid 80 s can be viewed as an attempt of "direct employment policy" in the public utilities and the public industrial sector, mainly in the basic (e.g. steel) machinery and chemical industry. In a sense, relatively large budget deficits and a s continuously increasing debt-to-GDP ratio have in the past often been excused by pointing at the fight against unemployment. The primary goal of this type of short-term policy in private goods markets was to stabilize employment and real income in the nationalized industry and, by means of the Austria specific inter-industrial relations and the multiplier process, in the private sector as well. To achieve this political target various steps were taken by the public management: the maintenance of the greatest possible level of production in the face of diminishing prices and demand; the greatest possible hoarding of employees even in situations when rationalization measures (dismissals) were required (resulting in unemployment on the job); an over-dimensioned propensity to invest (primarily with regard to the income effect of investment); an expansionist wage and fringe benefits policy with respect to buying power (causing high labor costs); and the financing of the firms' deficits out of the federal budget.

With regard to the social and re-election problems arising from unemployment and low incomes, the direct employment policy in public industrial firms intended to smooth the inevitable adjustment process to the rising requirements of global competitiveness in the long run. Naturally the pursued type of stabilization policy immediately caused substantial effects on the public 
industrial firms' productivity, thriftiness and profitability, thus reducing international competitiveness and augmenting deficits in the short run (Nowotny, 1982). Nonetheless, production and employment could not be maintained permanently at a high level, because the rationalization measures could not be postponed any longer. Since the mid 80s, the Austro-Keynesian stabilization policy has been increasingly criticized for what concerns its longterm efficacy. Finally, the troubling rise of the financial losses of the stateowned firms in the iron and steel, chemical, machinery and vehicle industry caused a turn in public opinion and economic policy. The amount of subsidies to public industrial firms covering the deficits and financing investment was limited to a fixed total and to the period until 1989. This change of policy emerged when the government realized that, due to the critique of the opposition, mass media and private entrepreneurs as well as to the people's fear of tax increases, a majority of voters would not tolerate any longer further subsidies to public industrial firms. In this sense, the repercussion from the voter to the government worked quite well in Austria. Prior to this change of mind politicians had formed coalitions with the management of the relatively big and locally concentrated public firms in order to secure the subsidies which rendered inefficiencies possible and served the local constituency. Moreover there have been powerful shop stewards who were at the same time members of the legislating National Council and therefore succeeded in financing the expansionist enterprise policy out of the federal budget. 
From the end of the 80 s there was a turn around in the Austrian policy with respect to the public industrial sector and public utilities. Not only took place quite a considerable privatization in the 90 s but also these enterprises where much less used for re-election purposes partly due to the fact that - as stressed already above - after joining the European Union and the deregulation of former monopolies into competitive markets it was much less attractive to use the public utilities and industries for re-election purposes. In the 90s the privatization of Austrian state owned industrial firms and state owned utilities has reached over the period 1993-1998 over 6 billions USD (compare figure 3.3). These dramatic changes in Austrian policies which gained momentum at the midst of the nineties let some authors even speak of "New Austrian Public Policies" (see, e.g., Clemenz, 1999, p. 1). Although a substantial privatization took place, the privatization potential in Austria is still quite large. In most cases, the Austrian government kept substantial shares of partly privatized enterprises. Considering the federal, the state and community level and including all public utilities, there is a privatization potential of 45 billion Euro from which the federal government owns $62 \%$, the city or state of Vienna $13 \%$, all other states (e.g. Upper and Lower Austria) 14\% and the communes (without Vienna) 11\%. The latest privatization proceeds of the federal government over the years 1999 up to 2001 are presented in table 3.6.

- Table 3.6 about here - 
In the year 1999 a part of the Austrian tobacco (9.4\%) has been privatized, which brought 6.8 billions Euro. On 28 February 2000, the Austrian Federal Government authorized the Minister of Finance to issue the privatization mandate to the "Österreichische Industrieholding AG" (OeIAG), the Republic of Austria's holding and privatization agency at the annual general meeting on 17 May 2000. In accordance with the mandate, OeIAG was required to transfer $100 \%$ of the following companies or interests in companies to completely new shareholders, strategic partners or the general public: Österreichische Staatsdruckerei GmbH, Dorotheum GmbH, Print Media Austria AG, Flughafen Wien AG, Österreichische Postsparkasse AG, Telekom Austria AG, and Austria Tabak AG.

In carrying out this privatization mandate in the interests of the Austrian people, the OeIAG had to " ... obtain the maximum revenue possible, taking into consideration the companies' and Austria's interests" (OeIAG, 2003). It is important to note that the OeIAG depends on the instructions issued by the Republic of Austria. A second phase was envisaged at that time which involves examining the possibility of even further privatization. In the meantime, the OeIAG has already privatized further companies or parts of companies like Österreichische Staatsdruckerei GmbH, Dorotheum GmbH, Flughafen Wien AG (17.4\%), Österreichische Postsparkasse AG, Austria Tabak AG, Print Media Austria AG, and Telekom Austria in compliance with the privatization mandate of the Federal Government. In the year 2000 100\% of the postal bank has been privatized and the proceeds were 970 millions Euro. Also 24\% of the 
state owned Telecom utility has been privatized with the proceeds of 763 millions Euro via an initial public offering. In sum in the year 20001.742 millions Euro of privatization proceeds have been achieved. In the year 2001 $41.1 \%$ of the Austrian tobacco state owned utility has been privatized, which brought privatization proceeds of 582.2 millions Euro. In sum, over the years 1999-2001 2.455 billions Euro privatization proceeds have been achieved. This is quite sizeable and helped the Austrian government to reduce the federal debt. However, some Austria-specific features deserve significantly more attention. ${ }^{12}$

\subsection{Economic Consequences of Privatization in Austria}

For Austria, aggregate productivity gains have not primarily come from intersectoral resource shifts. The contribution of these shifts between 2-digit SIC sectors to aggregate productivity change is quite small for Austria. ${ }^{13}$ Hence, a further promising candidate of explaining movements in the Austrian productivity time series is ownership respectively privatization. Both, the microeconomic and case study data are supportive of the positive effects of privatization over time on growth and employment (see, e.g., Davis et al. 2000, Megginson and Netter, 2001). These results reflect geographical diversity and are representative of a range of privatization experience in developing and transition economies. They hold for the European Union countries, but are less pronounced for transition and developing countries. The microeconomic evidence indicates that private firms are operationally more efficient then those, held by the state, particularly in competitive industries. ${ }^{14}$ A strong 
correlation is also found for European Union countries between privatization and growth. However, and consistent with the growth literature, privatization is likely surveying as a proxy in the regressions for one or more missing variables that may proudly be characterized as a favorable regime change. Public enterprises often seek to maintain employment, and benefit from staff budget constraints. Consequently, there is a concern that privatization may lead to increased unemployment. ${ }^{15}$ Also empirical evidence suggests that aggregate unemployment tends to decrease following privatization (although an identification problem might arise with respect to Austria due to the fact that country's period of main privatization efforts is superimposed by its EU entry). However, particular groups of workers may still be adversely effected. In general, there are good theoretical reasons for privatization and that the proceeds from privatization, if used in a clever fashion in the areas of education, technology and infrastructure, can increase the welfare of such countries. However, is this generally positive picture also applicable to the Austrian case?

What are the economic consequences from the privatization program for the Austrian Economy from 1990 on? It should first be mentioned that in the same period, i.e. together with the privatization a considerable amount of EU deregulation and liberalization (telecom-, gas-, electricity- and other service (...) markets) initiatives took place. Due to the upcoming of competitive markets in these areas and due to the gained efficiency of the privatized enterprises first considerable price reductions could be observed and second an 
additional growth of $0.1-0.32 \%$ per year took place over the period 1996 to $2001 .^{16}$ The origin of this additional growth was due to price reductions in the telecom-(-25\%), gas-(-12\%), electricity- $(-13 \%)^{17}$ sector resulting in cheaper input factors for the users and increased purchasing power for the consumers. In case of the partly privatized Austrian Telekom, solely the stifled competition and the EU directive to the observed effects on prices and the quality of output. Such an analysis is only to a limited extend possible for the now totally privatized VOEST, a steel mill, which today works in a totally different surrounding, compared to 1985 , when it was a $100 \%$ public enterprise. Here it does not make much sense to show the figures (e.g. turn over, profit, etc.) of this firm, which in former times disposed of totally different products and a production technology than today. Hence, we refrain from giving current realizations of performance measures and only feel legitimized to convey a rough indicator of performance of Voestalpine Stahl AG for the time span 1993-1997. The operating income rose from a 71 million ATS deficit to 3.2 billion ATS profits in 1997. However, even this impressive increase in performance cannot be attributed to a change in ownership rights in the sense of a statistically corroborated causality relationship (Nowotny, 1998, p. 43).

However, there are additional reasons why one should be very careful and not over-emphasize the above results. One reason is that the choice of firms for privatization has been far from random which might lead to an upward bias, i.e. to better than average performance results from privatization (Carlin et al., 2001, p. 3). Second, the effect of an ownership change might be quite different 
for different performance measures. Third, there might be additional influences behind the suspected impact of privatization on Austrian economic performance. For instance, reforms of the legal framework with respect to antitrust laws and competition policy and the abandonment of price regulations took place in Austria within the same period. In Austria, privatization came as a self-enforcing package with more prudent fiscal policies, liberalization and deregulation. ${ }^{18}$ Hence, the following analysis of the macroeconomic growth and employment contribution of privatization and its impacts on profitability of firms in general has to be conducted accepting these caveats. Why should we not only focus on the employment and growth impact of privatization in Austria but also care about the effect of privatization on the development of capital markets? New share listings on the Vienna stock exchange can directly create some net new wealth and a limited number of additional high-skilled jobs, but the main economic benefit from more efficient and liquid capital markets arises from the financing opportunities and monitoring possibilities these markets deliver. Moreover, efficient capital markets foster economic growth and grant individual firms to fund investment opportunities they otherwise would have to forgo (see ,e.g., Belke, Fehn and Foster, 2003). Hence, privatization appears valuable in view of whatever direct role it has played in promoting the highly underdeveloped stock market development in Austria (through new share offerings), and for the indirect role it might have had also in Austrian bond market development (Megginson and Netter, 2001, p. 44). 
We start with the discussion of the (un-) employment impacts of privatization in Austria, because this seems to be the politically most highlighted aspect of privatization in Austria. For OECD countries, among them Austria, current privatization receipts cannot be rejected empirically to have a significant negative effect on the current unemployment rate (implementation, new entry in the market), but a positive effect on the previous period's unemployment rate (announcement, restructuring). A potential explanation for this time pattern might be that when privatization and, thus, restructuring is announced firms feel inclined to operate more efficiently. If, as a next step, privatization is implemented, there is new market entry which increases labor demand and lowers unemployment (Katsoulakos and Likoyanni, 2002). Similar results can be found for instance in Megginson and Netter (2001) and some other studies for developing countries not to be cited here. However we would not like to push our interpretation of the Austrian case much further in view of the fact that the studies cited above do not give, for instance, fixed effects estimations of the idiosyncratic privatization impact in Austria. If the analysis is limited to the employment performance of Austrian firms after privatization, the general picture changes and one cannot reject the hypothesis of no change in employment after privatization. This is at least valid for Austria's early privatizations of Austria Microsystems, Austrian Airlines, Böhler-Uddeholm, Energieversorgung Niederösterreich, Flughafen Wien Schwechat, Flender, Immotrust, OMV, Voestalpine Eisenbahntechnik, Voestalpine Technologie, Voestalpine Stahl and Voith which took place from 1987 to 1995 
(Schaffhauser-Linzatti 2003). Moreover, in some cases production capacities were shifted towards foreign countries in the wake of privatization, in the case of Austria especially to Central and Eastern European countries (see e.g., the Semperit AG) which might overlap with the otherwise positive employment impact in Austria and create some empirical identification problems.

However, evidence is more ambiguous with respect to the impacts of privatizations on corporate performance in general. Some studies point towards the absence of a clear and unambiguous effect of changes in ownership on the economic performance of the affected firms and of the economy in general. Evidence that privatization enhances performance has not in all cases emerged from the Austrian data. For instance, Schaffhauser-Linzatti (2003) studies the change in operating and financial performance of Austrian firms Austria Microsystems, Austrian Airlines, Böhler-Uddeholm, Energieversorgung Niederösterreich, Flughafen Wien Schwechat, Flender, Immotrust, OMV, Voestalpine Eisenbahntechnik, Voestalpine Technologie, Voestalpine Stahl and Voith that were either partly or fully privatized during the period of 1987-1995. Using accounting data prior to and after the privatization, she measures the change in efficiency, profitability, capital structure, investment behavior, and employment (number of employees) for inflation- and business cycle-adjusted data. While profitability (i.e., the return on turnover, the return on equity and the return on total capital) and efficiency (alternatively measured as sales per employee, return per employee and staff costs per employee) display a significant change between the period of state 
ownership and privatization the other measures exhibit no significant change. Hence, she concludes that the Austrian privatization program was not that successful as compared to other international experience. Reasons for these originally not expected results are the small sample included in this study, the partial instead of total privatization of most of the enterprises and the structure of the management. Here, the number and the persons of the board of directors nearly was kept constant, so there were only few possibilities to install new management techniques and a new leadership of the privatized Austrian firms. Moreover, after privatization there was on average a decrease in salaries of board members by 2.6 percent indicating either a lack of incentives after privatization or too high salaries before privatization. ${ }^{19}$

Gugler (1998) aims to add to the knowledge about the effects of privatization on the economic performance of former state-owned enterprises (SOEs) in Austria. He assesses ownership structure (e.g., concentration) and the relative importance of the investor categories banks, the state, families, and domestic and foreign firms on the basis of a sample of 600 of the largest non-financial corporations. Balance sheet data, internal rates of return calculations and regression estimates show that not only ownership concentration, but also the identity of the large controlling shareholder is relevant to efficient governance of corporations. While foreign control increases profitability, particularly state control is detrimental to shareholder wealth maximization (see also Clemenz, 1999, p. 21). 
With respect to the capital market, it must not be forgotten that the "New Austrian" privatization policy significantly enhanced the role of the Vienna stock exchange itself. ${ }^{20}$ This can be highlighted by two measures. First, during the period 1992 to 1997 , around 45 percent of the total volume of new issues on the Vienna stock exchange consisted of issues by the OeIAG. Second, shares of privatized enterprises were responsible for 34.5 percent of the turnover on this stock exchange in the year 1997 (Nowotny, 1998, p. 43). Another important question is whether there has been a significant impact of privatization on the performance of the shares. In the years 1993 to 1997 , the performance of shares of privatized enterprises was significantly better than the trend increase of the Vienna stock exchange as a whole (Nowotny, 1998, p. 43). The relative importance of share issue privatizations (SIPs) in Austria can be read off from their relative position among Austrian firms in terms of the single firm's market capitalization as a percentage of the entire national market's year-end 1999. In Austria, privatized companies are the second most valuable firms (Megginson and Netter 2001, p. 43). Worldwide, large SIPs played a key role in the growth of capital markets almost everywhere, especially because they are generally among the largest firms in national markets. Davidson (1998) investigates 1,3,5, and 10-year market adjusted returns for these SIPs from five European countries (Austria, France, Italy, Spain, and the UK) through March 1997. After a long period of underperformance, averaging 1-1.5\% per year, he concludes that SIPs out-performed European market averages during the previous 12 months. 
With all the caveats of missing benchmarks (e.g., the trend of the Vienna stock exchange or the ATX as a whole!!) and missing thirds factors (overlap with speculative bubbles?) in mind and just for illustration purposes, we now finally focus on two recent individual examples of Austrian privatization, namely the Vienna Airport and Telekom Austria. Can we observe an increasing profitability, i.e. an increased value of the shares after privatization at the Vienna stock exchange? This view is certainly not corroborated with respect to Vienna Airport, but it cannot be excluded for Austrian Telekom (see Figures 4.1 and 4.2). Note: The date of complete privatization of Vienna Airport was March 2001. Its starting price at the Vienna stock exchange (closing) was 37.9 Euros, its price in April 2001 rose to 39.1 Euros. In the last two thirds of the sample the trend development of the airport shares was significantly negative. However, a totally different picture emerged from trade in Telekom shares which started in Vienna and New York on November 21, 2000. At the beginning, the 75 percent shareholder OeAIG announced a share price of 123.8 ATS respectively around 9 Euros. However, the price of Telekom shares (closing) fell immediately after the first privatization issue to a price of 6 euros in order to recover again and increase with a positive trend.

- Figures 4.1 and 4.2 about here -

Although the redemption of public debt itself is no sensible purpose of privatization $^{21}$, we finally address the fiscal effects/impacts of privatization on public budget deficits and on public debt. The reason is that exactly the 
budgetary impacts seem to be an important incentive for Austria's more recent strive for privatization. Katsoulakos and Likoyanni (2002) conduct an econometric analysis applying country level panel data of 23 OECD countries, among them Austria, for the period 1990 to 2000, analyzing the impact of privatization on public deficit, the impact on public debt. They are able to show that privatization receipts are not significantly correlated with budget deficit for the whole OECD sample, Austria being part of it. They also identify a statistically significant and negative relation between privatization receipts and public debt for the whole OECD sample which again includes Austria. However, any sound assessment of budget impacts of privatization in Austria should consider that especially in this country a higher number of sales is not at all correlated with higher proceeds (Bortolotti, Fantini and Siniscalco, 2001, p 21, see also section 4).

\section{Some Extensions On Privatization in Austria}

\subsection{Backlogs of Privatization and Their Elimination By the Recent Centre-right Coalition}

In the last sections we claimed significant backlogs of privatization in Austria, even if one takes into a account a potentially limited capacity of the Vienna stock exchange. One very intuitive example in this respect is the privatization of the two largest Austrian Banks which became a long-lasting and cumbersome process, if not a tragedy, from 1987 on. The latter was mainly due to political quarrels and arguments of the usual 'too-big-to-fail' kind and would 
by itself justify a separate public choice analysis (Aiginger 1999, pp. 14 ff., Belke 2000a, EIRO 2002). ${ }^{22}$ However, privatization gained momentum under Austria's centre-right coalition government which came into power in February 2000, and was mainly intended to help to balance the budget (the so-called Austrian "Nulldefizit" target). We take this episode as evidence in favor of the hypothesis that the democratic repercussions from the voter who fear tax increases if privatization would have been postponed any longer to the government functions in Austria today as well as in the past. Hence, one necessary condition for the emergence of politically motivated 'privatization' cycles, as we would like to call it, are still given especially in this country. Obviously, the new government including the FPÖ has initiated a comprehensive reform process, including extensive privatization. It claims that Austria has successfully privatized the majority of its large manufacturing firms and will continue privatization in order to consolidate the budget. Following the successful sales of the postal savings bank, Oesterreichische Postsparkasse AG (PSK) to the banking group BAWAG, and of stakes in Vienna airport, Vienna's famous auction house, the Dorotheum, and cigarette manufacturer Austria Tabak to Gallagher Group of the UK, and the privatization of all hospitals in Upper Austria in 2001, further privatization in 2002 was hoped to be successful. The biggest Austrian privatization in history was the sale of Telekom Austria to Telecom Italia for $€ 1.979$ billion for a $25 \%$ minority holding. A fourth mobile license was recently sold to Germany's Telekom Service GmbH \& Co. KG for $€ 98$ million. 
The correctness of our diagnosis of significant backlogs in the Austrian process of privatization is underlined by a recent study which confirms that the German civil law tradition negatively affects the probability of privatization. Bortolotti, Fantini and Siniscalco, 2001, p. 30ff., cannot reject empirically the hypothesis that countries like Austria seem particularly reluctant to privatize as opposed to common law countries. Moreover, Austria was not able to maintain its position in the top group in the current International Employment Ranking by the Bertelsmann Foundation. This gives some additional support to the main hypothesis of this contribution, namely that governments always time privatizations with an eye on their impacts on the performance of the labor market and thus on re-election probabilities. It states that the Austrian economy and the labor market are burdened in particular by high state intervention manifesting itself in abundant government outlays and a still high degree of regulation. However, the new government is endeavoring an extensive trimdown of the state and the administration (Bertelsmann Foundation 2002). In the same vein, the Austrian reform commission ("Ausgabenreformkommission") has tested the performance of the government institutions and has recommended that the state confines itself to certain central tasks.

Finally, the importance of headquarters with high-value services, R\&D with higher incomes in their surroundings is emphasized quite often (see, e.g., Aiginger in Austrian Parliament, 2000). According to his reasoning, Austria up to now has too few headquarters. With an eye on this deficiency, one of the objectives of the privatization of Voestalpine AG declared during the 
extraordinary general meeting of the OeIAG on $7^{\text {th }}$ April 2003 has been that the decision-making headquarters of privatized former SOEs are maintained in Austria. Most strikingly and in strict accordance with the partisan view of privatization described later on, the decision-making headquarters of the company to be privatized shall be maintained in Austria if possible through the creation of Austrian core shareholders (OeIAG, 2003).

\subsection{The Political Economy of Austrian Privatization - The Roles of Ideology and Opportunism}

One further important stylized fact about Austria is that the role of this country's financial market has remained marginalized up to now. Hence, the varieties of possibilities to sale public assets as a constitutional element of privatization are severely limited (EIRO 2002). It seems to be quite important to understand and, hence, to take into account already at this stage of analysis that the government's choice of the privatization method itself and the resulting effects on income distribution reflect policy priorities (OECD 2002, p. 52, Bortolotti and Pinotti 2003). From this perspective and analogous to the wellknown 'opportunistic' and 'partisan' political business cycles, not only reelection incentives as stressed in the sections 2 and 3, but also ideological purposes behind (a) non-privatization versus privatization or (b) choice of the privatization method come into play. For example, it should be taken into account that Austria has no substantial history of buying and selling shares on the stock market. Until the midst of the nineties, Austrian managers dealt 
almost exclusively with banks (Aiginger 1999, Aiginger and Mooslechner 1997, EIRO 1999). Banks in a bank-dominated financial system like in Austria have a vested interest in financing state-owned enterprises with soft budget constraints and, hence, are inclined to delay and obstruct privatization in order to preserve the status quo. However, this is only valid as long as the SOEs are relatively profitable. Hence, in the Austrian case growing non-profitability of the SOES could explain the recent impetus for privatization in spite of the existence of pressure groups like banks (Bortolotti, Fantini and Siniscalco, 2001, p. 3).

However, especially in the UK and the French cases which were highlighted in section 3 , the speed and the amount of privatization was significantly shaped by partisan politics and not only by the above mentioned pressure groups like, for instance, banks. Privatization in the UK was part of a whole "right-wing" Thatcherism package and French privatization was a decisive element of the now-famous Mitterand U-turn in economic policies towards a "right-wing" orientation. Hence, we feel inclined to suppose that also in Austrian privatization there was more in it than pure interest group pressure, opportunism of politicians with respect to the voters will or, even more naïve, a rational policy towards more efficiency of large Austrian enterprises. In this sense, some important questions not investigated in section 3.3 are the following: What were the ideological/partisan motives for privatization in the Austrian case? Was privatization guided by the incentive to gain revenues or to balance losses which would mean that financial motives of the seller were 
dominant? What role do the aims of increasing productive efficiency, i.e. the reduction of average costs, and of enhancing allocation efficiency, i.e. the increase of the consumer surplus, play in the implicit politico-economic model of the privatization process in Austria which we already developed in section $2 ?{ }^{23}$ Has this model to be augmented by ideological/partisan aspects?

In sections 2 and 3.3, we stated that political business cycle (PBC) considerations in general play an important role in explaining the existence and the slow speed of removal of oversupply of public services and that this is especially so in Austria with its former Austro-Keynesian type of stabilization policy. However, one should be careful in concluding that a slowdown in privatization efforts is necessarily in the interest of the government. The reason is that policy priorities like maximizing the value of proceeds from privatization might themselves be a function of re-election considerations (populist governments). This is especially valid from a partisan theory of political business cycles point of view. Privatization can be considered as a right-wing party issue as demonstrated by Austria's younger history. However, the emergence of regular political business cycles, i.e. cyclical up- and downturns of macro variables, dependent on election dates, the political business cycle (PBC) à la Nordhaus (1975) and the Rogoff (1990) rational political business cycle (RPBC) is less likely. What has to be expected, instead, are different level of asset sales during privatization waves which are dependent on the ideology of the government (Aiginger, 1997, p. 351, Belke 2000). We already stated that the Social Democrats and the trade unions 
initially opposed to Austria's EU entry which paved the way for more privatization. It seems to be very interesting for further research whether these considerations could lead, if developed further, to a revival of the opportunistic-ideological political business cycle à la Frey and Schneider in a different public economics context (Frey and Schneider, 1978).

Bortolotti and Pinotti (2003) provide an empirical analysis of the role of political institutions in privatization. Their empirical testing relies on a new political database with continuous and time-varying measures of the politicalinstitutional setting, and of the partisan orientation of the executive. Using panel data for 21 industrialized countries in the 1977-1999 period, among them continental European countries like Austria, the authors show that the likelihood and the extent of privatization are positively associated with majoritarian political systems with a low number of veto players. In consensual proportional democracies like Austria, privatization tends to be delayed by "war of attrition" among different political actors.

Strikingly, such a partisan determinant of the choice of the privatization method can be identified for countries like Austria with the following arguments. Right-wing executives with re-election concerns (as the recent "right-wing" coalition in Austria) design privatization to spread share ownership among domestic voters. Clear evidence of the relevance of this view for Austria is for instance given by the by now more concrete definition of the privatization mandate, the OEIAG has now been commissioned to examine 
two privatization options for Voestalpine AG, namely through the stock market and through the acquisition of company stock by financial investors. One of the main objectives is that the company maintains an Austrian core shareholder structure (see Oesterreichische Industrieholding AG, 2003). Even in a more general context, it is said that the privatization project to be completed by OEIAG in accordance with the mandate from the federal government should lead to the maintenance of the decision-making headquarters of the company to be privatized in Austria if possible through the creation of Austrian core shareholder structures (OeIAG, 2003). ${ }^{24}$

By selling underpriced shares in the domestic retail market and not abroad ${ }^{25}$, right-wing governments attract the median voter, shape a constituency interested in the maximization of the value of financial assets and averse to redistribution policies to the left. Perotti (1995) and Biais and Perotti (2002) present models of how SIP terms can be structured to achieve certain policy objectives. Perotti (1995) demonstrates that a market-oriented ("right-wing") government tends to underprice a relatively large portion of a SOE in the initial offer to convey a signal to investors that this government will not interfere with the privatized enterprise in the future. Since the value of a privatized firm is higher without interference, an efficient signal generally amplifies the degree of underpricing. On the other hand, a populist ("left-wing”) government, which ex definitione gives in to political pressure to interfere with the privatized firm, will definitely not underprice the SIP to the same degree. The reason is that the populist ("left-wing") government prefers to raise more issue proceeds in the 
short term, rather than signal a commitment it cannot keep and, hence, is not credible. ${ }^{26}$ In fact, for Austria there is first evidence that the mean underpricing of initial public offerings of former SOEs is 6.5 percent for the period 1984 to 1999 which was dominated by government participation of the ÖVP and a sample of 76 cases (Aussenegg, 1997).

From this point of view, especially in Austria there is clear evidence of strategic privatization as a rational strategy to raise the probability of success of market-oriented coalitions at future elections. ${ }^{27}$ With this emphasis on ideology and partisan aspects, we contradict Nowotny (1998), p. 46, who states: "In Austria, both economists and politicians have shown a greater tendency to follow a more general, non-ideological approach with respect to privatization issues".

Does this insight stand in contrast to some tendencies of parts of former Austrian SOEs to be sold to foreigners? We would argue no and give an example for this (Economist, 2003). The proposed flotation of one-third of Voestalpine in late September 2003 for an estimate $€ 450 \mathrm{~m}$-plus $(\$ 494 \mathrm{~m})$ has induced many Austrians to accusations like that it is an unpatriotic sell-out to foreigners or that the market is being manipulated. Seemingly in contrast to our preferred partisan approach, Wolfgang Schüssel's right-wing coalition government has been shaken by these discussions.

However, Voestalpine is not an ordinary company. Founded by the Nazis after the "Anschluss" (Union) with Germany in 1938 as the Hermann-Göring-Werke 
in Linz, the steel mill became the flagship of Austria's state-owned industry and of trade unions and the Socialist Party. After a brush with bankruptcy, the partial privatization in the mid-1990s already mentioned in section 3 and diversification into car parts and rail systems, Voestalpine changed into one of Europe's most profitable steel groups and the pride of Linz and the surrounding province of Upper Austria.

Hence, after secret talks with Magna International, a Canadian car-parts group, about a possible takeover and break-up of Voestalpine, the finance minister $\mathrm{Mr}$ Grasser had to promise that Voestalpine would not be taken over by foreigners and would definitely not be split up. He suggested a private sale to selected investors, but the European Commission in Brussels finally denied it. So Grasser and Schuessel instead proposed a public share offer-with a clear corporatist flavor. Instead of organizing road shows to solicit the highest bids from international fund managers, the state holding group OEIAG gave a few weeks' notice and began to assemble investors who are already owners of around $30 \%$ of Voestalpine. Their leader is Ludwig Scharinger, a big banker close the People's Party. Assured of his support, Mr Schuessel declared that Voestalpine would stay in the control not only of Austrians but of Upper Austrians. In the same vein, he accepts a much lower price for Voestalpine to keep it in familiar hands (corresponding to our hypothesis of underpricing). Freedom Party people still fight against foreign takeovers and request that further privatization should be stopped. The Economist (2003) accurately describes the current Austrian situation emphasizing again the importance of 
voter repercussions in the Austrian context: “ ... But the rumpus may have scared foreign investors away. That, it seems, is what Austrian voters want”.

With an eye on ideological/partisan impacts described above, which institutional framework is necessary for successful privatization in Austria? Here, one could derive some lessons from the Austrian experience with respect to the institutional framework needed for a successful privatization, stressing for instance the eventual role of a more professional privatization agent than the OeIAG is in monitoring the privatization process (Aiginger 1999). In Table 3.2, the data for Austria refer only to privatizations by the central government (OECD 2002, pp. 46 f.). The general Austrian approach to privatization by the state (as opposed to privatization by state-owned banks) has generally been to downsize in terms of employment only very moderately by general social or pension plans. However, privatization enacted by state-owned banks like in the cases of the tyre maker Semperit AG (which a few years ago left Austria and now produces in the Czech Republic) and of Steyr-Daimler-Puch AG (shares of which were bought by the mogul Frank Stronach and which after privatization displayed a good performance due to, e.g., technical innovations) led to significant labor shedding (EIRO 1999). Hence, the choice of the privatization agent seems to matter for employment impacts of privatization and thus for the probability of re-election cycles. In this sense, "leftist" as opposed to "rightist" governments which tend to refrain from significant labor shedding should prefer privatization by the state. Is this partisan determinant of the choice of the privatization method significant and consistent throughout? 
The answer is no, since in order to get re-elected (and then follow ideological partisan interests) even right-wing governments can be expected to be opportunistic in a sense by always having an eye on a sufficient employment performance (Frey and Schneider, 1978). According to section 4.1, this seems to correspond with Austrian history and the choice of the OeIAG as the privatization agency. If these kind of considerations would not have played a decisive role in Austrian privatization policy, a bottom-up system with pouvoirs for the OEIAG had to be installed instead of the actual top-down model, in which the government sets the guidelines. ${ }^{28}$

\subsection{Why Are Some Sectors in Austria Privatized and Others Not?}

We now comment on why specific sectors were privatized and others were not. To which extent can this selection be explained by public choice considerations? Two examples are instructive in this respect. First, the autonomy and the financial basis of Austrian universities were strengthened in view of the problems in the education sector. Student fees that flow directly to the universities have been introduced. Why have the relevant pressure groups been able to prevent the long-awaited 'privatization' of this important sector until the start of the new century? Second, like in many other industrial nations, also in Austria the labor market suffers from a severe qualification mismatch. Hence, policy makers took some measures to promote a more efficient use of labor force potentials. Most remarkable, the Austrian government authorized the operation of the first private job placement services already in 1992 and 
expanded it to all sectors of the labor market only two years later. Private agencies in this field work under the same conditions as the Austrian labor market service ("Arbeitsmarktservice" or AMS). However, the share of private services in the overall number of providers is still extremely low. Is this due to the well-known and still highly relevant insider-outsider problem on the labor market? Or more generally speaking: How strong has the relative influence of external shareholders and employee representatives been over company restructuring in Austria? Most remarkably in this respect, recent evidence seems to demonstrate that privatization has had no impact on industrial relations in Austria (EIRO 1999, 2002). In the past, trade-unions had an influential position within the OeAIG and in the single companies as well via their membership in the advisory boards (Nowotny, 1998, p. 43). Only recently, on September 5 2003, 300 steel workers gave voice to their anger against the privatization of the last 35 percent of the once fully state owned steel works Voestalpine in Linz, Upper Austria, when the state holding company OEIAG was meeting to finalize the privatization deal. In the same vein, Austrian interests must in accordance with the mandate of the OeIAG from the federal government be protected in the course of privatization by the creation and maintenance of secure jobs in Austria (OeIAG, 2003).

However, one could argue that the increasing ownership by foreigners will weaken the traditional system of "social partnership" considerably in the future. Within this informal but powerful body of employers' and employee's associations, each member group of social partners which in each case is close 
to one of the two large political parties followed significant special interests. Since each party favored privatization in the domain of the other (Social Democrats for instance in the area of agriculture or of entrepreneurship, Conservatives in the area of the nationalized industry). This party-"ideological" view significantly almost certainly contributes to an explanation of the only recently resolved deadlock of privatization efforts in Austria. Already in the year 1999 it became obvious that several larger firms including Austrian owned ones have begun to cut back their contributions to employers' associations (Clemenz, 1999, p. 22). Seen on the whole, the role of social partners for instance in cartel courts hampers workable competition and has to be reduced in order to reap the full gains of privatization.

\subsection{Changes in the Institutional Environment of the Austrian Economy and the Speed of Privatization}

Our last remarks relate to certain changes in the institutional environment for the Austrian economy which might have had an important impact on the speed of privatization in this country. One obvious candidate for such a change is Austria's EU entry (1995). (Why) Can it serve as an important structural break with respect to privatization efforts? One potential answer would be to point to the fact that the Austrian system of subsidies has had to be abandoned or modified as a necessary condition of entry. However, the key point here is that the process of privatization and the accompanying liberalization and deregulation have become irreversible and immune against the objections of 
major lobbies in Austrian politics and economics (Clemenz, 1999, p. 22). Where does this lock-in effect come from? First, as shown in section 3.4, in some areas like in the Austrian telecommunication sector consumers have profited very much as compared to the time of state monopoly. Hence, there is no obvious reason for the median voter to argue in favor of re-establishing a state monopoly. Second, international commitments like Austria's membership in the EU and treaties connected with it are not easy to reverse. ${ }^{29}$ Third, many foreign firms have entered the Austrian market in the wake of Austria's EU entry which by itself have changed the ownership structure considerably. There is no way out for Austrian firms from competing with these FDIs.

Another important politico-economic aspect stressing the benefits of Austria's EU entry is that EU-membership was an opportunity to implement overdue reforms. Due to the inevitability and comprehensiveness of the reform steps connected with EU entry and due to the fact that the EU became a suitable "whipping boy" for reforms against the interests of some party clientel, timeconsuming struggles about these steps became obsolete. Moreover, potential external effects of privatization in only one sector become internalized now, resolving the deadlock between the interest groups described above (Clemenz, 1999, p. 19).

It is again important to note a "partisan" (ideological) component in this respect. The Austrian ministry of foreign affairs, for most of the post war period a permanent job of the Social Democrats, was taken over by the smaller 
partner of the big coalition, the Conservatives, in the year 1987. This change in ideology of the foreign minister finally paved the way for determined efforts of Austria to join the European Community and meet the European policy standards after the fall of the iron curtain (by which the Soviet Union which regularly exercised its right to veto against Austria's EU entry disappeared from the scene) and, finally, also for meeting the Maastricht criteria as an important prerequisite to join European Monetary Union. Apart from the increasing dissatisfaction with the poor performance of the SOEs (especially the Austrian telecommunication monopolist) at that time, partisanship was thus again decisive for enabling a structural break in privatization incentives as already discussed earlier in this contribution.

However, there is a second natural candidate of a change in Austria's institutional environment triggering privatization, namely the Austrian exchange rate regime. To what extent can the intensity of privatization be traced back to the specific exchange rate regime as an important external constraint? In the preceding sections, we only touched upon this very interesting issue. Our guess would be that the increase of privatization might also be a facet of Austria's convergence to the euro zone countries, since similar degrees of privatization might imply inter alia a higher correlation of country-specific business cycles. Hence, one possible interpretation would be that an accelerating speed of privatization in Austria represents one cornerstone on Austria's way to form an optimum currency area with the euro zone (see, e.g., Hochreiter and Winckler, 1995). However, one might even go further and 
suspect that also Austria's strong intentions to become a first-wave member of European Monetary Union had an amplifying impact on its privatization efforts. Due to its close ties to the DM, the financial markets expected Austria to be in almost for sure. Hence, Austria had to prepare itself for the increasingly fierce competition within a single currency area by fostering privatization of inefficient SOEs (Jeronimo, Pagan and Soydemir, 2000).

A third candidate for a break in incentives with respect to privatization is one of the conditions for EMU entry, namely the Maastricht debt criterion. Already Germany and France in 1998 are said to have sold their "family silver" in order to push their debt below the 60 percent of GDP threshold. However, there is a coincidence with the accumulation of privatization efforts towards the end of the nineties. Hence, it appears logical to also ask how much of Austria's privatization efforts in the nineties was enacted in order to fulfill the Maastricht debt criterion and later on to obey the stability pact, or at least was sold to the public as such. ${ }^{30}$ In this sense, governments would be tempted to use privatization receipts in order to reduce their public debt in order to meet one convergence criterion.

We already pointed out in section 3 that in France privatization activities were highest in 1998, the year before the launch of the euro, due to a privatization of France Telecom. Based on similar motives, the current Austrian government has generally pursued a (in economic terms) liberal and market-oriented economic policy, which has focused on privatization and a reduction of state 
influence on business. In line with this, the electricity sector was opened to competition in September 2001 leading to lower prices for customers and more competitiveness of Austria's electricity industry. In addition, bureaucratic procedures in doing business in Austria have been simplified. One of the government's main concern, however, has been to achieve a balanced budget in order to satisfy the EU's Stability and Growth Pact (SGP). ${ }^{31}$ In 1999, Austria's budget deficit exceeded the EU-set Maastricht criteria of a maximum budget deficit of 3 percent, which had drawn severe criticism from the EU (The irony of history being that at the end of the year 2003 Austria is legitimized to accuse the large euro area countries of disregarding the rules of the Stability and Growth Pact). While aiming to reach a zero budget in 2002, the Austrian finance minister Grasser was able to announce achievement of this goal in November 2001. In our understanding, this had on the one hand been due to an unexpectedly sharp increase in Austrian tax revenue in 2001, as revenues from corporation tax and income tax rose significantly and debt servicing costs decreased. In addition, the states and municipalities assisted in balancing the federal budget as they accrued budget surpluses. On the other hand, however, the need to lower the budget deficit served as a strong (but only indirect) stimulus for privatization efforts in order to raise additional revenues by increased efficiency of the Austrian economy. ${ }^{32}$

At this stage of analysis, it is important to note that privatization proceeds are only allowed to have an impact on the public debt but not on the public deficit. Privatization proceeds must not be included in the public deficit in Maastricht 
definition according to the EC directive 3605/93 of the Council from November 22, 1993. This is a point often neglected by authors writing on Austrian privatization and the fiscal Maastricht criteria and also not always clear in Austrian political circles (see, e.g., Nationalrat der Republik Österreich, 1996, p. 19). Seen on the whole, thus, the Austrian case is a good example of how external constraints can discipline a "consensus oriented" country. It seems fair to state that without EU-membership and the strive for meeting the Maastricht criteria, the evidence in favor of "New Austrian Public Policies" and increasing privatization activity would have been much weaker than it already is.

Although beneficial for themselves, the main aim of privatizations should not as a rule primarily be to finance and lower public debt for political purposes. Otherwise privatization would tend to serve short-run objectives instead of promoting long-run goals, such as fostering productivity. In this case, the standard purpose of privatizations, the improvement of competitiveness and profitability of former SOEs is under-emphasized at the benefit of the aim of repaying outstanding of debt which, however, is not necessarily welfare enhancing. However, the latter was given a high priority in recent Austrian laws and directives (Austrian Parliament 2000). Instead, the revenues from privatization should only be used for the creation of new assets in the areas of education, R\&D, technology and infrastructure (Katsoulakos and Likoyanni 2002, p. 13, Schneider 2002). 


\section{Summary and Conclusions}

Privatization has certainly been a key-element of structural reform in the European Union countries including Austria and proceeds from privatization have been substantial in most of these countries. Gross receipts that can be transferred to the budget are effected by actions prior to sale, the sales process and the post-privatization regime. An evaluation of the potential uses of privatization receipts or proceeds should reflect the implications for government net worth and their macroeconomic impact. In so far as government net worth is concerned, proceeds from privatization do not often themselves indicate that the government is better off. Privatization has longer term implications in terms of revenues forgone and/or expenditures that will not be made in the future and government decisions on the use of proceeds should reflect this inter-temporal effects. Government net worth will rise to the extent that private sector ownership leads to an increase in efficiency and the government shares in this gain.

The macroeconomic effects of privatization depend, in part, on whether receipts/proceeds are from domestic or foreign sources, the degree of capital mobility and the exchange regime. Broadly the effects of a decrease in the deficit financed by privatization receipts would be similar to those resulting from a debt financed fiscal expansion. Both the economic recovery and privatizations lead to receipts which can be used to lower the deficit. The use of proceeds to reduce external debt provides for an automatic sterilization of 
what may be substantial capital inflows associated with privatization. The reduction of domestic debt may impact domestic stability.

This contribution has shown that there are good reasons for privatization in general although this strategy raises some opportunity costs and that the privatization proceeds are able under certain circumstances to enhance the welfare of these countries. With regard to Austria we are skeptical about whether Austria's privatization potential has been exploited up to now and whether the speed of privatization, although quite sizeable, has really been sufficient. However, future prospects for quick and full privatization in Austria are rather gloomy although economic theory (Alchian and others) and also empirical evidence suggest that only full as opposed to partial privatization is successful with respect to a better economic performance in the long run (Boardman and Vining, 1989, 1991). However, as long as politicians interfere with this process, there will be no straight development towards full privatization. This assessment is all the more valid with an eye on the Austrian habit to appoint former members of the Austrian government as CEOs at the Austrian privatization agency OEIAG and the state is still determined to keep a strategic stake in the latter. According to the statute of the Österreichische Industrieholding AG, “ $\ldots$ Austrian interests must be protected as follows: ... the creation and maintenance of secure jobs in Austria, ... maintenance of the decision-making headquarters of the company to be privatized in Austria..." (Österreichische Industrieholding AG, 2003). However, one glimmer of hope currently is that Austrian Finance Minister Karl-Heinz Grasser does not stop to 
reiterate in December 2003 that the state will sell all of its remaining stake in Telekom Austria, despite some calls to keep a blocking minority. The state privatization agency OeIAG, charged by the government with selling off most of Austria's industrial holdings, holds 47 percent of Telekom and is now charged by the centre-right government with selling it by late 2006 . This seems to be extremely important since otherwise a continued holding would only slow down Telekom Austria in adapting to a fast moving telecoms market. 
Table 3.1: Worldwide Privatizations between 1980 and 1996

\begin{tabular}{|c|c|c|c|c|}
\hline \multirow[b]{2}{*}{ Source } & \multirow[b]{2}{*}{ Region } & \multicolumn{2}{|c|}{ Number of Enterprises } & \multirow[b]{2}{*}{ Years } \\
\hline & & Large Enterprises & Small Enterprises & \\
\hline $\operatorname{EBRD}(1996)^{1)}$ & Transformation countries & 51.500 & 274.700 & $1990-96$ \\
\hline $\operatorname{OECD}(1996)^{1)}$ & Transformation countries & 44.600 & 253.200 & $1990-96$ \\
\hline THA (1994) & East Germany & 13.800 & 35.000 & 1990-94 \\
\hline Kikeri, Nellis, Shirley (1994) & World & 4.000 & - & $1980-92$ \\
\hline Sader (1993) & World & 1.800 & - & $1980-92$ \\
\hline In sum & World & $>65.000$ & $>300.000$ & $1980-96$ \\
\hline
\end{tabular}

${ }^{1)}$ Without East Germany and China.

Source: Siegmund (1998). 'World' means worldwide except the transition countries and East Germany. 
Table 3.2: Privatization of State-owned Enterprises: Global Amount Raised from Privatization, 1990-2000

\begin{tabular}{|c|c|c|c|c|c|c|c|c|c|c|}
\hline & $\begin{array}{c}1 \\
1990 / 91 \\
\\
\text { Million } \\
\text { USD } \\
\end{array}$ & $\begin{array}{c}2 \\
1992 / 93 \\
\\
\text { Million } \\
\text { USD } \\
\end{array}$ & $\begin{array}{c}3 \\
1994 / 95 \\
\\
\text { Million } \\
\text { USD }\end{array}$ & $\begin{array}{c}4 \\
1996 / 97 \\
\\
\text { Million } \\
\text { USD }\end{array}$ & $\begin{array}{c}5 \\
1998 / 99 \\
\\
\text { Million } \\
\text { USD } \\
\end{array}$ & $\begin{array}{c}6 \\
2000 \\
\\
\text { Million } \\
\text { USD } \\
\end{array}$ & $\begin{array}{c}7 \\
\text { Total 1990- } \\
2000 \text { (sum of } \\
1-6 \text { ) } \\
\text { Million USD }\end{array}$ & $\begin{array}{c}\text { 8 } \\
\text { GDP } 2000 \\
\\
\text { Billion } \\
\text { USD } \\
\end{array}$ & \begin{tabular}{|c|}
9 \\
Total 1990- \\
2000 in \% of \\
2000 GDP
\end{tabular} & $\begin{array}{c}10 \\
\text { Invest. of } \\
\text { SOE in \% of } \\
\text { total } \\
\text { investment } \\
1978-1991 \\
\end{array}$ \\
\hline Austria & 80 & 191 & 1,735 & 3,954 & 2,564 & 2,083 & 10,607 & 266.3 & 3.9 & 6.2 \\
\hline Belgium & n.a. & 956 & 3,297 & 3,039 & 2,277 & n.a. & 9,569 & 316.1 & 3.0 & 8.8 \\
\hline Denmark & 644 & 122 & 239 & 411 & 4,521 & 111 & 6,048 & 205.6 & 2.9 & 13.5 \\
\hline Finland & n.a. & 229 & 1,529 & 1,746 & 5,713 & 1,827 & 11,044 & 165.8 & 6.6 & n.a. \\
\hline France & n.a. & 12,160 & 9,615 & 13,288 & 22,460 & 17,438 & 74,961 & $1,755.6$ & 4.2 & 14.5 \\
\hline Germany & 325 & 435 & 240 & 14,353 & 7,098 & n.a. & 29,549 & $2,680.0$ & 1.1 & 11.6 \\
\hline Greece & n.a. & 35 & 117 & 1,953 & 8,772 & 1,384 & 12,261 & 138.1 & 8.8 & 17.9 \\
\hline Ireland & 515 & 344 & 157 & 293 & 4,846 & 1,458 & 7,613 & 104.8 & 7.2 & n.a. \\
\hline Italy & n.a. & 1,943 & 13,927 & 33,984 & 39,230 & 9,728 & 98,812 & $1,204.9$ & 8.2 & 12.5 \\
\hline Luxembourg & n.a. & n.a. & n.a. & n.a. & n.a. & n.a. & n.a. & 24.7 & n.a. & n.a. \\
\hline Netherlands & 895 & 780 & 7,759 & 2,070 & 1,816 & 310 & 13,630 & 494.6 & 2.7 & 8.1 \\
\hline Portugal & 2,390 & 2,826 & 3,557 & 7,932 & 5,884 & 3,256 & 25,845 & 128.0 & 20.2 & 16.6 \\
\hline Spain & 172 & 4,043 & 4,399 & 15,201 & 12,582 & 1,079 & 37,476 & 702.4 & 5.3 & 10.7 \\
\hline Sweden & n.a. & 630 & 3,165 & 1,840 & 2,243 & 8,082 & 15,960 & 276.8 & 5.7 & 16.0 \\
\hline UK & 34,731 & 9,127 & 8,032 & 12,154 & n.a. & n.a. & 64,044 & $1,294.4$ & 4.9 & 11.0 \\
\hline EU 15 & 39,752 & 33,821 & 57,768 & 112,218 & 120,006 & 46,756 & 410,321 & $9,758.1$ & 4.2 & n.a. \\
\hline Norway & 73 & n.a. & 639 & 695 & 454 & 1,039 & 2,900 & 170.5 & 1.7 & 22.7 \\
\hline Switzerland & n.a. & n.a. & n.a. & n.a. & 4,426 & n.a. & 4,426 & 337.0 & 1.3 & n.a. \\
\hline Turkey & 730 & 989 & 1,973 & 758 & 1,816 & 2,712 & 8,978 & 205.1 & 4.3 & 35.7 \\
\hline
\end{tabular}


Table 3.2. Continued: Privatization of State-owned Enterprises: Global Amount Raised from Privatization, 1990-2000

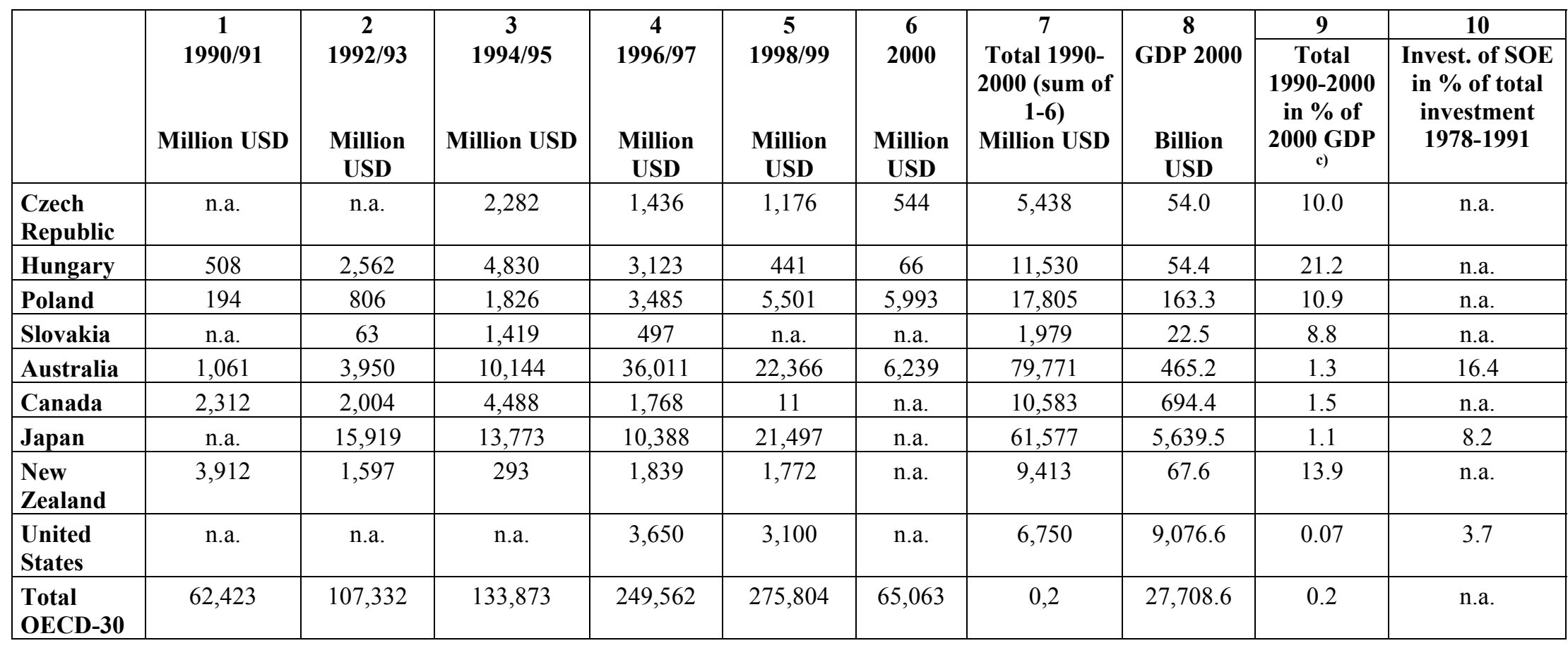

Sources: OECD (2001), Financial Market Trends, here: no 79, June; OECD (2001), Main Economic Indicators, December, World Bank (1996) and CESifo calculations.

See also for privatization through public share offerings: CESifo (2003), DICE database Tables "Privatization of State-owned Enterprises Through Public Share Offerings 1961-2000: Issue Size per Country" and "Privatization of State-owned Enterprises Through Public Share Offerings, 1961-2000: Number and Names of Enterprises". 
Table 3.3: Privatization of State-owned Enterprises Through Public Share Offerings, 1961-2000: Issue Size per Country (Million USD)

\begin{tabular}{|c|c|c|c|c|c|c|c|c|c|c|}
\hline & 1961-89 & 1990-91 & $1992-93$ & 1994-95 & 1996-97 & 1998-99 & $2000^{\text {a) }}$ & Tot. 1961-2000 & $\begin{array}{c}\text { Tot. 1990-99 } \\
\text { (only PSO) }\end{array}$ & $\begin{array}{l}\text { OECD }{ }^{b)} 1990-99 \\
\text { (all priv.) }\end{array}$ \\
\hline Austria & 662 & n.a. & 211 & 1,086 & 733 & n.a. & n.a. & 2,692 & 2,030 & 8,524 \\
\hline Belgium & n.a. & n.a. & n.a. & 2,571 & 1,100 & n.a. & n.a. & 3,671 & 3,671 & 9,569 \\
\hline Denmark & n.a. & n.a. & n.a. & 3,006 & n.a. & n.a. & n.a. & 3,006 & 3,006 & 5,937 \\
\hline Finland & 367 & n.a. & 214 & 800 & 285 & 5,573 & 1,900 & 9,139 & 6,872 & 9,217 \\
\hline France & 15,478 & 780 & 9,695 & 19,263 & 12,261 & 24,982 & 1,770 & 84,229 & 66,981 & 57,523 \\
\hline Germany & 4,536 & n.a. & n.a. & 730 & 13,300 & 10,624 & \begin{tabular}{|l|}
17,460 \\
\end{tabular} & 46,650 & 24,654 & 22,415 \\
\hline Greece & n.a. & n.a. & 33 & n.a. & 2,365 & 2,794 & n.a. & 5,192 & 5,192 & 10,877 \\
\hline Ireland & n.a. & 136 & n.a. & n.a. & n.a. & 4,300 & n.a. & 4,436 & 4,436 & 6,155 \\
\hline Italy & 1,157 & 695 & 2,481 & 10,220 & 34,462 & 36,190 & n.a. & 85,205 & 84,048 & 89,084 \\
\hline Luxembourg & n.a. & n.a. & n.a. & n.a. & n.a. & n.a. & n.a. & n.a. & n.a. & n.a. \\
\hline Netherlands & 2,278 & n.a. & n.a. & 11,632 & n.a. & n.a. & n.a. & 13,910 & 11,632 & 13,320 \\
\hline Portugal & 434 & 1,829 & 2,375 & 2,255 & 6,428 & 5,998 & n.a. & 19,319 & 18,885 & 22,589 \\
\hline Spain & 2,326 & n.a. & 3,193 & 3,950 & 13,432 & 21,652 & n.a. & 44,553 & 42,227 & 36,379 \\
\hline Sweden & 165 & n.a. & 364 & 3,765 & n.a. & n.a. & 8,800 & 13,094 & 4,129 & 7,878 \\
\hline UK & 51,766 & 27,908 & 7,360 & 6,200 & 5,649 & n.a. & n.a. & 98,883 & 47,117 & 64,044 \\
\hline EU 15 & 79,169 & 31,348 & 25,926 & 65,478 & 90,015 & 112,113 & 29,930 & 433,979 & 324,880 & 363,511 \\
\hline Switzerland & n.a. & n.a. & n.a. & n.a. & n.a. & 5,600 & \begin{tabular}{|l|} 
n.a. \\
\end{tabular} & 5,600 & 5,600 & 4,426 \\
\hline Japan & 82,402 & n.a. & 7,312 & 3,400 & 6,440 & 46,500 & n.a. & 146,054 & 63,652 & 61,577 \\
\hline USA & 1,650 & n.a. & n.a. & n.a. & n.a. & 1,425 & n.a. & 1,425 & 1,425 & 6,750 \\
\hline
\end{tabular}

Sources: Megginson (2000), B. Bortolotti et al. (2000), OECD (2000), here: no. 76, 07-2000, and CESifo (2003). 
Table 3.4.: Privatization of State-owned Enterprises Through Public Share Offerings, 1961-2000: Number and Names of Enterprises

\begin{tabular}{|c|c|c|}
\hline & $\begin{array}{l}\text { No. of enterprises } \\
\text { priv. }\end{array}$ & Names of enterprises privatized \\
\hline Austria & 10 & $\begin{array}{l}\text { Austria Mikro Systeme, Austria Tabak, Austrian Airlines, Böhler Uddeholm, Flughafen Wien, ÖMV } \\
\text { Aktiengesellschaft (Mineralöl), VA Technologie (as a separation from VOEST), Verbund Energie-Versorgung } \\
\text { Niederösterreich (EVN), Voest- Alpine Eisenbahnsysteme, Vorarlberger Kraftwerke (VKW). }\end{array}$ \\
\hline Belgium & 2 & Belgacomm, Credit Communal de Belgique. \\
\hline Denmark & 2 & Copenhagen Airport, Tele Danmark AS. \\
\hline Finland & 8 & Finnair, Fortum, Kemira, Outokumpu, PT Finland Group, Sonera, Rautaruukki, Valmet. \\
\hline France & 34 & $\begin{array}{l}\text { Aerospatiale, Agence Havas, Air France, Alcatel Alsthom, Assurances Generales de France [AGF], Banque } \\
\text { Nationale de Paris, Banque de Batement et des Traveaux Publics, Banque Industrielle \& Mobiliere Privee } \\
\text { (BIMP), Banque Paribas, Caisse Nationale de Prévoyance, Compagnie Financiere de Suez, Compagnie Generale } \\
\text { D’Electricite, Credit Commercial de France, Credit Local de France, Credit Lyonnais, Elf Acquitaine, France } \\
\text { Telecom, Machines Bull, Matra, Pechiney, Renault, Rhone- Poulenc, Saint Gobain, Seita, SGS-Thomson, } \\
\text { Societe Generale, Sogenal Mar, STMicroelectronics, Television Francaise, Thomson- CSF, Total S.A., Union } \\
\text { Des Assurances De Paris, Usinor Sacilor, Wanadoo. }\end{array}$ \\
\hline Germany & 10 & $\begin{array}{l}\text { Deutsche Siedlungs- und Landesrentenbank (DSL), Deutsche Telekom, Deutsche Verkehrs- Kredit- Bank, } \\
\text { Industrie Verwaltungsgesellschaft (IVG), Jenoptik, Lufthansa, T-Online, VEBA AG, VIAG, Volkswagen AG. }\end{array}$ \\
\hline Greece & 6 & $\begin{array}{l}\text { Athens Stock Exchange, General Helenic Bank, Hellenic Petroleum, Hellenic Sugar Industries, National Bank of } \\
\text { Greece, OTE: }\end{array}$ \\
\hline Ireland & 2 & Greencore (formerly Irish Sugar Corporation), Telecom Eireann. \\
\hline Italy & 20 & $\begin{array}{l}\text { AEM, Aeroporti die Roma, Alitalia May, Autostrade, Banca Commerciale Italiana, Banca di Roma, } \\
\text { Banca Nazionale de Lavoro, Bando di Napoli, Credito Italiano, Enel, Eni, Enimont, Instituto } \\
\text { Mobiliare Italiano, Istituto Bancario San Paolo, Istituto Nazionale D.Assicurazioini, Istituto San Paolo } \\
\text { di Torino, Saipen, Societa Finanziaria, Telecom Italia, Telefonica (STET). }\end{array}$ \\
\hline Luxembourg & - & \\
\hline Netherlands & 5 & $\begin{array}{l}\text { KLM Royal Dutch Airlines, Koninklije PTT Nederland, KPN, Naamloze Venootschap DSM, NMP } \\
\text { Postbank. }\end{array}$ \\
\hline Norway & 1 & Christiana Bank. \\
\hline
\end{tabular}


Table 3.4. Cont. Privatization of State-owned Enterprises Through Public Share Offerings, 1961-2000:No. and Names of Enterpr.

\begin{tabular}{|c|c|c|}
\hline & No. of enterpr. priv. & Names of enterprises privatized \\
\hline Portugal & 22 & $\begin{array}{l}\text { Banco Espirito Santo e Comercial de Lisboal, Banco Fomento Exterior, Banco Fonsecas \& Burney, Banco } \\
\text { Pinto \& Sotto Mayor, Banco Portugues do Atlantico, Banco Totta \& Acores, Brisa- Auto Estradas, Centralcer, } \\
\text { CIMPOR, Companhia de Seguros Bonanca, Companhia Maceira Pataias, Crédito Predial Portugues, } \\
\text { Electricidade de Portugal, Imperio, Mundial Confianca, Petrogal, Portugal Telecom, SECIL, Sociedad } \\
\text { Financeira Portuguesa, Tranquilidade, Uniao de Bancos Portugues, Unicer. }\end{array}$ \\
\hline Spain & 11 & $\begin{array}{l}\text { Aceralia, Argentaria Corp., Endesa May, Gas Natural, Gas y Electricidad de Espana (GESA), Indra, Red } \\
\text { Electrica Espanola, Repsol May, Retevision, Tabaclera, Telefonica. }\end{array}$ \\
\hline Sweden & 6 & Assi Domän, Pharmacia, Procordia, Stadshypotek, Svenskt Stal AB (SSAd), Telia. \\
\hline UK & 44 & $\begin{array}{l}\text { AEA Technology, Amersham International, Anglian Water plc., Associated British Ports, BAA plc (British } \\
\text { Airpots Authority), British Aerospace, British Airways, British Energy, British Gas, British Petroleum, British } \\
\text { Steel, British Telecommunications, Britoil, Cable and Wireless, East Midlands Electricity plc., Eastern } \\
\text { Electricity plc., Enterprise Oil, Jaguar plc., London Electricity plc., Manweb plc., Midlands Electricity plc., } \\
\text { National Power, North West Water Group plc., Northern Electric plc., Northumbian Water Group plc., } \\
\text { Norweb plc., Power Gen, Railtrack May, Rolls Royce, Scottish Hydro- Electric, Scottish Power, SEEBOARD } \\
\text { plc., Severn Trent plc., South Wales Electricity plc., South West Water plc., South Western Electricity plc., } \\
\text { Southern Water plc., Southern Electric plc., Thames Water plc., Welsh Water plc., Wessex Water plc., } \\
\text { Yorkshire Electricity Group plc., Yorkshire Water. }\end{array}$ \\
\hline Switzerland & 1 & Swisscom. \\
\hline Japan & 7 & $\begin{array}{l}\text { Japan Airlines, Japan Railroad East, Japan Tobacco, JR West, KDD, Nippon Telegraph and Telephone, NTT } \\
\text { DoCoMo. }\end{array}$ \\
\hline USA & 3 & T\&T, Consolidated Rail Corp., United States enrichment Corp. \\
\hline
\end{tabular}

Sources: W.L.Megginson, 2000), Bortolotti et al. (2000), and CESifo calculations. See also tables "Privatization of State-owned Enterprises Through Public Share Offerings, 1961-2000: Dates and Amount", "Privatization of State-owned Enterprises: Global Amount Raised from Privatization, 1990-1999". 
Table 3.5.: Privatization proceeds in small open economies in the years 1993, 1995, 1997, 1998 and 2000

\begin{tabular}{|c|c|c|c|c|c|c|c|c|c|c|c|c|c|c|c|}
\hline \multirow[t]{3}{*}{ Country } & \multicolumn{15}{|c|}{$\begin{array}{l}\text { Privatization proceeds in small open economies } \\
\end{array}$} \\
\hline & \multicolumn{3}{|c|}{1993} & \multicolumn{3}{|c|}{1995} & \multicolumn{3}{|c|}{1997} & \multicolumn{3}{|c|}{1998} & \multicolumn{3}{|c|}{2000} \\
\hline & $\begin{array}{c}\$ \\
\text { Million }\end{array}$ & $\begin{array}{c}\text { in \% } \\
\text { of } \\
\text { Total }\end{array}$ & Rank & $\begin{array}{c}\$ \\
\text { Million }\end{array}$ & $\begin{array}{c}\text { in \% } \\
\text { of } \\
\text { Total }\end{array}$ & Rank & $\begin{array}{c}\$ \\
\text { Million }\end{array}$ & $\begin{array}{c}\text { in \% } \\
\text { of } \\
\text { Total }\end{array}$ & Rank & $\begin{array}{c}\$ \\
\text { Million }\end{array}$ & $\begin{array}{c}\text { in \% } \\
\text { of } \\
\text { Total }\end{array}$ & Rank & $\begin{array}{c}\$ \\
\text { Million }\end{array}$ & $\begin{array}{c}\text { in \% } \\
\text { of } \\
\text { Total } \\
\end{array}$ & Rank \\
\hline Austria & 142 & $4 \%$ & 7 & 1.035 & $9 \%$ & 4 & 2.020 & $17 \%$ & 2 & 2.935 & $12 \%$ & 5 & 2.083 & $11 \%$ & 3 \\
\hline Belgium & 956 & $29 \%$ & 1 & 2.681 & $22 \%$ & 2 & 1.562 & $13 \%$ & 3 & 1.467 & $6 \%$ & 7 & - & - & - \\
\hline Denmark & 122 & $4 \%$ & 8 & 10 & $0 \%$ & 9 & 45 & $0,5 \%$ & 8 & 4.502 & $18 \%$ & 2 & 111 & $1 \%$ & 8 \\
\hline Finland & 229 & $7 \%$ & 6 & 363 & $3 \%$ & 7 & 835 & $7 \%$ & 5 & 1.999 & $8 \%$ & 6 & 1.827 & $10 \%$ & 4 \\
\hline Ireland & 274 & $8 \%$ & 4 & 157 & $1 \%$ & 8 & 293 & $3 \%$ & 7 & 4.864 & $19 \%$ & 1 & 1.458 & $8 \%$ & 5 \\
\hline Island & 10 & $0 \%$ & 9 & 6 & $0 \%$ & 10 & 4 & $0 \%$ & 10 & 129 & $0,5 \%$ & 10 & - & - & - \\
\hline Netherlands & 780 & $24 \%$ & 2 & 3.993 & $33 \%$ & 1 & 831 & $7 \%$ & 6 & 335 & $0,5 \%$ & 9 & 310 & $2 \%$ & 7 \\
\hline Norway & - & - & - & 521 & $4 \%$ & 6 & 35 & $0,5 \%$ & 9 & 28 & $0 \%$ & 11 & 1.039 & $6 \%$ & 6 \\
\hline Portugal & 500 & $15 \%$ & 3 & 2.425 & $20 \%$ & 3 & 4.968 & $43 \%$ & 1 & 4.271 & $17 \%$ & 4 & 3.256 & $18 \%$ & 2 \\
\hline Sweden & 252 & $8 \%$ & 5 & 852 & $7 \%$ & 5 & 1.055 & $9 \%$ & 4 & 172 & $1 \%$ & 8 & 8.082 & $44 \%$ & 1 \\
\hline Switzerland & - & - & - & - & - & - & - & - & - & 4.426 & $18 \%$ & 3 & - & - & - \\
\hline Total & 3,265 & $100 \%$ & & 12,043 & $100 \%$ & & 11,648 & $100 \%$ & & 25,128 & $100 \%$ & & 18,166 & $100 \%$ & \\
\hline
\end{tabular}

$-\quad=$ Null or insignificant

Source: Own calculations with the help of table 3.2. 
Table 3.6: Latest Privatization proceeds in Austria (Federal government) over 1999-2001

\begin{tabular}{|c|c|c|}
\hline Year & Public Enterprise & Proceeds (Mio. Euro) \\
\hline 1999: & Privatization of $9,4 \%$ of the Austrian Tabacco AG & 6.8 Mio. Euro \\
\hline \multirow[t]{2}{*}{ 2000: } & \multirow[t]{2}{*}{$\begin{array}{ll}100 \% & \text { PSK (Postal Bank) } \\
24.4 \% & \text { Telecom (to Telecom Italia) } \\
100 \% & \text { State Printing Office }\end{array}$} & $\begin{array}{r}\text { 969.5 Mio. Euro } \\
\text { 763.8 Mio. Euro } \\
2.2 \text { Mio. Euro } \\
\end{array}$ \\
\hline & & 1,742.3 Mio. Euro \\
\hline \multirow[t]{2}{*}{ 2001: } & \multirow[t]{2}{*}{$\begin{array}{ll}17.38 \% & \text { Airport Vienna AG } \\
41.1 \% & \text { Austrian Tabacco AG } \\
100 \% & \text { Dorotheum } \\
100 \% & \text { Strohal Rotary Printing }\end{array}$} & $\begin{array}{r}\text { 54.1 Mio. Euro } \\
\text { 582.2 Mio. Euro } \\
55.6 \text { Mio. Euro } \\
\text { 21.1 Mio. Euro }\end{array}$ \\
\hline & & 713.0 Mio. Euro \\
\hline Sum & $1999-2001$ & 2,455.3 Mio. Euro \\
\hline
\end{tabular}

Source: Ministry of Economic Affairs (2002). 
Figure 3.1.:Privatization Proceeds in percent of GNP in small open economies in the years 1993, 1995, 1998 and 2000

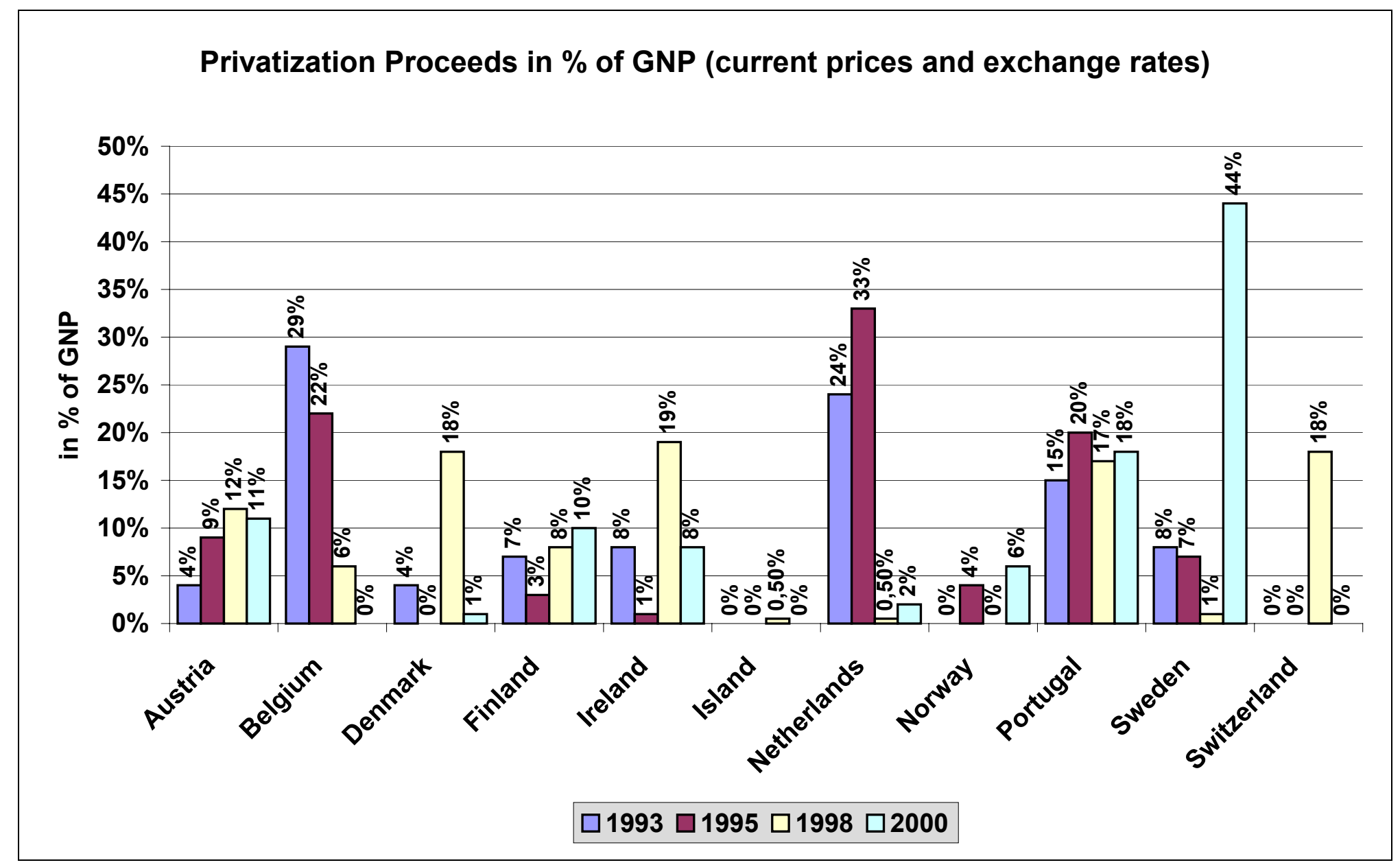


Figure 4.1: Performance of shares of Vienna Airport at the Vienna Stock Exchange

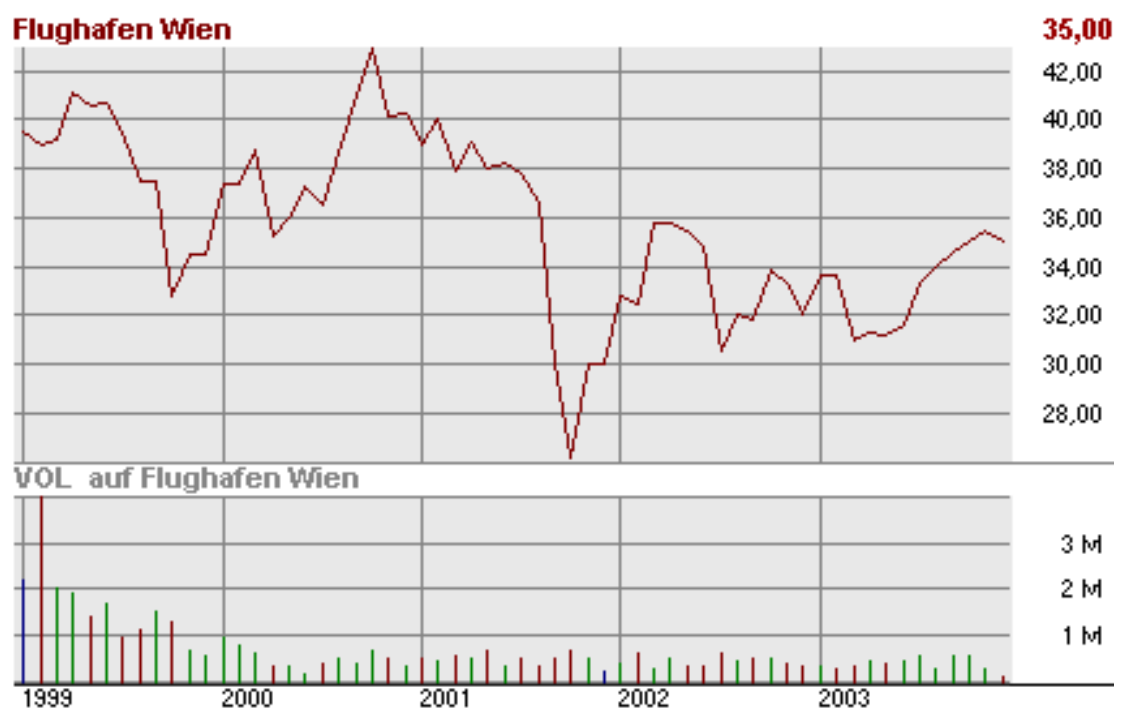

G003 TeleTrader.com

Source: Vienna Stock Exchange (2003). VOL means trade volume.

Figure 4.2: Performance of shares of Telekom Austria at the Vienna Stock Exchange

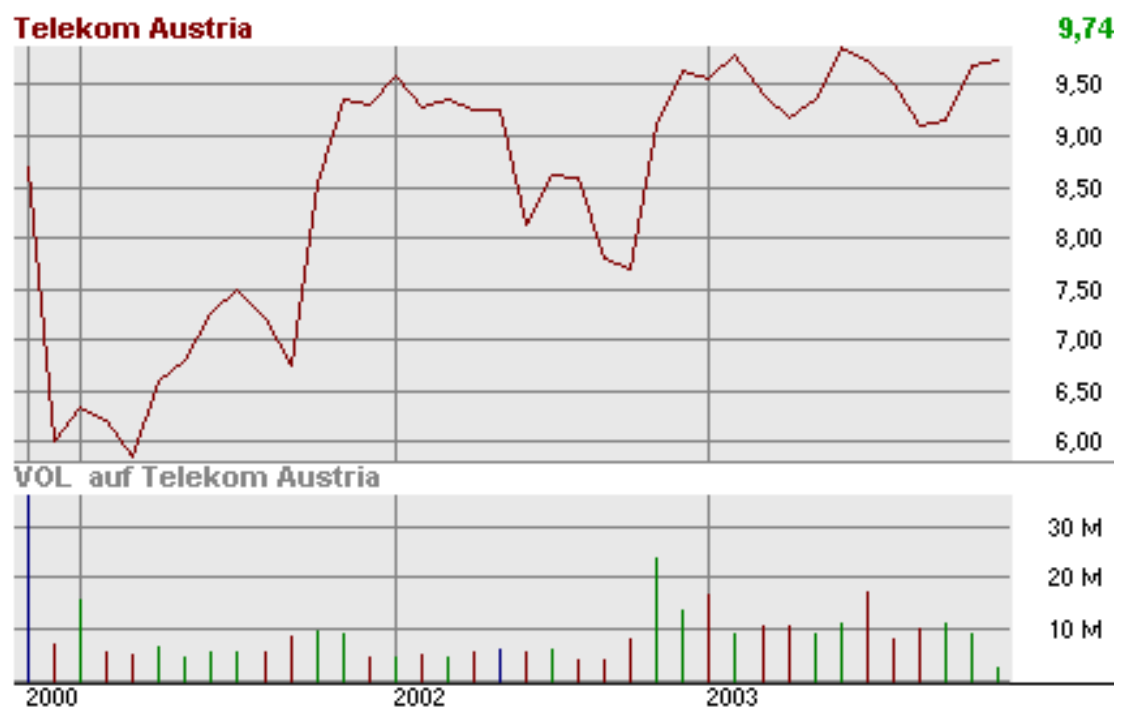

(1) 2003 TeleTrader.com

Source: Vienna Stock Exchange (2003). VOL means trade volume. 


\section{References}

Aiginger, Karl (1997), Privatisierung in Österreich, Österreichisches Jahrbuch für Politik, Wien- München.

Aiginger, Karl (1999), The Privatization Experiment in Austria, in: Austrian Economic Quarterly, 4/1999, pp. 261-270.

Aiginger, Karl, Mooslechner, P. (1997), Framework Conditions, Methods and Processes of Privatization: Lessons from a Trade Sale of an Austrian Bank, $11^{\text {th }}$ Plenary Session of the OECD Advisory Group on Privatization, September 18 to 19, Rome.

Alchian, Armen A. (1961), Some Economics of Property Rights, Rand Corporation, Santa Monica.

Alchian, Armen A. (1965), Some Economics of Property Rights, Il Politico 30/4, pp. 816-829.

Aussenegg, Wolfgang (1997), Short and Long-Run Performance of Initial Public Offerings in the Austrian Stock Market, Working Paper no. 24, Austrian Working Group on Banking and Finance, August, Vienna.

Aussenegg, Wolfgang (2000), Privatization versus Private Sector Initial Public Offerings in Poland in: Multinational Finance Journal, Vol. 4, pp. 69-99.

Austrian Parliament (2000), Parlament Industrieausschuss, Parlamentskorrespondenz/02/13.04.2000/Nr. 199, Vienna.

Baron, M. and P. Myerson (1982), Regulating a Monopolist with Unknown Costs, in: Econometrica, Vol. 50, pp. 911-930.

Bartel, Rainer and Friedrich Schneider (1991), The "Mess" of Public Industrial Production in Austria: A Typical Case of Public Sector Inefficiency?, Public Choice Vol. 68/1, pp. 17-40.

Belke, A. (2000), Political Business Cycles in the German Labour Market? Empirical Tests in the Light of the Lucas-Critique, in: Public Choice, Vol. 104, pp. 225-283.

Belke, A. (2000a), Too Big to Fail: Bankenkonkurs und Wählerstimmenkalkül, in: von Delhaes, D., Hartwig, K.-H., Vollmer, U. (Hrsg.), Monetäre Institutionenökonomik, Schriften zu Ordnungsfragen der Wirtschaft, Band 67, Lucius \& Lucius, Stuttgart, pp. 261 - 297.

Belke, Ansgar, Fehn, Rainer and Neil Foster (2003), Venture Capital Investment and Labor Market Performance - A Panel Data Analysis, forthcoming in: Keuschnigg, Christian, Kanniainen, Veas (Hrsg.), Venture Capital, Entrepreneurship and Public Policy, CESifo, MIT Press, Cambridge/MA. 
Bertelsmann Foundation (Ed., 2002), International Employment Ranking, Guetersloh/Germany.

Biais, Bruno and Enrico Perotti (2002), Machiavellian Privatization, in: American Economic Review, Vol. 92, pp. 240-258.

Boardman, Anthony E., and Aidan R. Vining (1989), Ownership and Performance in Competititve Environments: A Comparison of the Performance of Private, Mixed and State-Owned Enterprises, in Journal of Law and Economics, Vol. 32, pp. 1-33.

Boardman, Anthony E., and Aidan R. Vining (1991), The Behavior of Mixed Enterprises, in: Research in Law and Economics, Vol. 14, pp. 223-250.

Boes, Dieter and Friedrich Schneider (1996), Private Public Partnership: Gemeinschaftsunternehmen zwischen privaten und der oeffentlichen Hand, Zeitschrift fuer Unternehmens- und Gesellschaftsrecht, pp. 519-543.

Borcherding, Thomas, W.C. Bush and R.M. Spann (1977), The Effects on Public Spending on the Divisibility of Public Outputs in Consumption, Bureaucratic Power and the Size of the Tax Sharing Group, in: T.E.Borcherding (editor), Budgets and Bureaucrats: The Sources of Government Growth, Durham, N.C., pp. 211-228.

Borcherding, Thomas, Werner W. Pommerehne and Friedrich Schneider (1982), Comparing the Efficiency of Private and Public Production: The Evidence from 5 Countries, Zeitschrift fuer Nationaloekonomie/Journal of Economics 89 (Supplement 2), pp. 127-156.

Bortolotti, Bernardo, Pinotti, Paolo (2003), The Political Economy of Privatization, Nota di Lavoro 45.2003, Fondazione Eni Enrico Mattei, Venice.Bortolotti, Bernardo, Fantini, Marcella and Domenico Siniscalco (2001), Privatisation Around the World - New Evidence from Panel Data, Nota di Lavoro 77.2001, Fondazione Eni Enrico Mattei, Venice.

Bortolotti, Bernardo, D'Souza, Juliet, Fantini, Marcella and William L. Megginson (2000), Sources of Performance Improvement in Privatized Firms: A Clinical Study of the Global Telecommunications, Paper presented at the London Business School Conference on the Global Telecommunications Industry, May 2001.

Boutchkova, Maria K., and William L. Megginson (2000), Privatization and the Rise of Global Capital Markets, in: Financial Management, Vol. 29, pp. 31-76.

Carlin, Wendy, Fries, Steven, Schaffer, Mark E., and Paul Seabright (2001): Competition and Enterprise Performance in Transition Economies: Evidence from a Cross-country Survey, CEPR Discussion Paper no. 2840, Centre for Economic Policy Research, London.

CESifo (2003): DICE Database, Munich. 
Clemenz, Gerhard (1999): Privatization, Liberalization and Deregulation The Austrian Experience, Paper to be presented at the ISNIE-Conference 1999, Session: Public Policies and Industrial Structures, Washington/DC, September 17-19, 1999.

Communist Party of Austria (2003), E-Wirtschaft in globaler Kapitalhand, Web: http://www.kpoe.at/bund/archiv/antiprivatisierung/ewirtschaft.htm.

Davidson, Richard (1998), Market Analysis: Underperformance Over?, Privatisation International Yearbook, London: IFR Publishing.

Davis, Jeffrey, Ossowski, Rolando, Richardson, Thomas, and Steven Barnett (2000), Fiscal and Macroeconomic Impact of Privatization, IMF Occasional Paper 194, Washington/DC.

De Alessi, Louis (1974), An Economic Analysis of Government Ownership and Regulation: The Theory and the Evidence from Electric Power Industry, Public Choice, Vol. 19/1, pp. 1-42.

EIRO (1999), Privatization and Industrial Relations, European Industrial Relations Observatory, Ireland, Web: http://www.eiro.eurofound.ie/1999/12/word/at9909168s.doc, accessed January 15, 2003.

EIRO (2002), Comparative Study Questionnaire on 'Industrial Restructuring: the Impact of Variations in Forms of Corporate Governance', European Industrial Relations Observatory, Ireland, Web: http://www.eiro.eurofound.ie/2002/09/word/AT0207203S.doc, accessed January 15, 2003.

Frey, Bruno S., and Friedrich Schneider (1978), An Empirical Study of PolitoEconomic Interaction in the United States, in: Review of Economics and Statistics, Vol. 60, pp. 174-183.

Grossman, S. and O. Hart (1983), An Analysis of the Principal-Agent Problem, in: Econometrica, Vol. 51, pp. 7-45.

Gugler, Klaus (1998), Corporate Ownership Structure in Austria, in: Empirica, Vol. 25, pp. 285-307.

Hochreiter, Eduard, Winckler, Georg (1995), The Advantage of Tying Austria's Hands - The Success of the Hard Currency Strategy, in: European Journal of Political Economy, Vol. 11, pp. 83-111.

Jeronimo, Venilde, Pagan, José A., and Gökçe Soydemir (2000), Privatisation and European Economic and Monetary Union, in: Eastern Economic Journal, Vol. 26, pp. 321-334.

Jones, Steven L., Megginson, William L., Nash, Robert C. and Jeffry M. Netter (1999), Share Issue Privatizations as Financial Means to Political and Economic Ends, in: Journal of Financial Economics, Vol. 53, pp. 217253. 
Katsoulakos, Yannis, Likoyanni, Elissavet (2002), Fiscal and Other Macroeconomic Effects of Privatization, Nota di Lavoro 113.2002, Fondazione Eni Enrico Mattei, Venice.

MasColell, M., G. Winston and P. Green (1995), Microeconomic Theory, Oxford: Oxford University Press.

Megginson, William L. (2000), Sample of Firms Privatized Through Public Share Offerings, 1961-Aug. 2000, Web: http://facultystaff.ou.edu/M/William.L.Megginson-1/

Megginson, William L., and Jeffry M. Netter (2001), From State to Market - A Survey of Empirical Studies on Privatization, in: Journal of Economic Literature,Vol. 39, pp. 321-389.

Ministry of Economic Affairs (2000), Latest Privatization Proceeds in Austria (Federal Government), Vienna.

Nationalrat der Republik Österreich (1996), Stenographisches Protokoll der 41. Sitzung des Nationalrates der Republik Österreich, XX. Gesetzgebungsperiode, Donnerstag, 3. Oktober 1996, Wien.

Niskanen, W.A. (1971), Bureaucracy and Representative Government, Chicago and New York, Chicago University Press.

Niskanen, W.A. (1975), Bureaucrats and Politicians, Journal of Law and Economics 18/4, pp. 617-643.

Nordhaus, William D. (1975), The Political Business Cycle, in: Review of Economic Studies, Vol. 42, pp. 169-190.

Nowotny, E. (1998): Privatization, Deregulation, Reregulation - Experiences and Policy Issues in Austria, in: Journal for Institutional Innovation, Development, and Transition, Vol. 2, pp. 35-49.

Nowotny, Ewald (1982), Nationalist Industry As an Instrument of Stabilization Policy, Annalen der Gemeinwirtschaft 51/1, pp. 41-57.

Österreichische Industrieholding AG (2003): OEIAG - Österreichische Industrieholding AG: http://www.oeiag.at/english/OeIAG/privatisierung.shtm.

OECD: Financial Market Trends, Various issues, Paris.

OECD: Main Economic Indicators, Various issues, Paris.

Pardo, José Casas and Friedrich Schneider (1996), Current Issues in Public Choice, Cheltenham, UK, Edward Elgar Publishing Company.

Perotti, Enrico (1995), Credible Privatization, American Economic Review, Vol. 85, pp. 847-859.

Rogoff, Kenneth (1990), Equilibrium Political Business Cycles, in: American Economic Review, Vol. 80, pp. 21-36. 
Schaffhauser-Linzatti, Michaela (2003): Ökonomische Konsequenzen der Privatisierung in Osterreich: Eine empirische Analyse anhand boersennotierter Aktiengesellschaften, in: Zeitschrift für Betriebswirtschaft, Vol. 73, No. 1, January 2003, pp. 49-71.

Schaffhauser-Linzatti, Michaela, and Engelbert Dockner (1999): The Financial and Operating Performance of Privatized Firms in Austria, mimeo, University of Vienna.

Schneider, F. (2002): Privatisierungen und Deregulierungen in Oesterreich in den 90er Jahren: Einige Anmerkungen aus Sicht der neuen politischen Oekonomie, in: Berg, H. (ed.), Deregulierung und Privatisierung: Gewolltes - Erreichtes - Versaeumtes?, Schriften des Vereins fuer Socialpolitik (Neue Folge, Band 287), pp. 89-120.

Schneider, Friedrich (1997): Deregulierung und Privatisierung als Allheilmittel gegen ineffiziente Produktion von oeffentlichen Unternehmen?, in: Wieviel Staat, wieviel Privat?, Sammelband der Arbeitsgemeinschaft der wissenschaftlichen Wirtschaftspolitik, Vienna, pp. 33-59.

Schneider, Friedrich (2002): Privatisierungen und Deregulierungen in Oesterreich in den 90er Jahren: Einige Anmerkungen aus Sicht der neuen politischen Oekonomie, in: Hartmut Berg (editor), Deregulierung und Privatisierung: Gewolltes - Erreichtes - Versaeumtes?, Schriften des Vereins fuer Socialpolitik (Neue Folge, Band 287), pp. 89-120.

Schneider, Friedrich and Markus F. Hofreither (1990), Privatisierung und Deregulierung in oeffentlichen Unternehmen in westeuropaeischen Laendern: Erste Erfahrungen und Analysen, Vienna: Manzsche Verlags- und Universitaetsbuchhandlung.

Schneider, Friedrich und Bruno Frey (1988), Political Business Cycles: A Survey, in: Thomas Willet (editor), Inflation and the Political Business Cycles, Durham, N.C., pp. 239-275.

Siegmund, Ulrich (1998), Die Treuhand 1990/1991: Spezialfall, Privatisierungsmonopol und Staatsversagen?, Universitaet Kiel: Institut fuer Weltwirtschaft, Kiel.

The Economist (2003), Don't Sell Our Family Silver! Austrians Are Still Reluctant Free-Marketeers, Sep 4th 2003.

Vienna Stock Exchange (2003): Österreich/Börse Wien, Aktien, Web: http://vlbg.rdg.ttweb.net/ frm/index.asp, December $1^{\text {st }}$.

World Bank (1996), Bureaucrats in Business - The Economics and Politics of Government Ownership, Washington/DC. 


\section{Endnotes}

${ }^{1}$ Surveys of the privatization literature is provided in Megginson and Netter (1999), Heller (1990), Boes and Schneider (1996), Bartel and Schneider (1991) and a summary for the earlier discussion is given in Borcherding, Pommerehne and Schneider (1982).

${ }^{2}$ Compare e.g. Borcherding, Pommerehne and Schneider (1982) and Boes and Schneider (1996).

${ }^{3}$ The first approach has been developed by Alchian $(1961,1965)$ and more recently Baron and Myerson (1982), Grossman and Hart (1983) and MasColell, Winston and Green (1995).

${ }^{4}$ Compare the study by Boes and Schneider (1996), Schneider (1997, 2002), Schneider and Hofreither (1990). As these results are so well known, they are not reported here.

${ }^{5}$ Compare Schneider and Frey (1988), Bartel and Schneider (1991) and Pardo and Schneider (1996) and Schneider (2002).

${ }^{6}$ E.g. in Austria, the states Upper Austria and Styria, compare Schneider (2002) and Bartel and Schneider (1991).

${ }^{7}$ The Austrian type of Keynesian policy used the public enterprises and state owned firms for such purposes quite successfully over the period 1971-1986. Compare part 3.3 and Schneider (2002) and Schneider and Bartel (1992).

${ }^{8}$ See, for instance, Aiginger in Austrian Parliament (2000).

${ }^{9}$ Compare also Bortolotti, Fantini and Siniscalco (2001) and Schneider (2003).

${ }^{10}$ See among others Aiginger (1999). Nowotny (1998), pp. 39 ff., discusses different meanings of ,privatization' more deeply in the context of Austria.

${ }^{11}$ See Clemenz (1999) and Nowotny (1998), pp. 37 ff., on Austrian public enterprises as instruments of economic and social policy as a means of avoiding labor market hysteresis (Theory of Co-operative Economics or "Gemeinwirtschaft").

${ }^{12}$ A further comprehensive and informative source of the history of privatization in Austria is Clemenz (1999), pp. 5ff.

${ }^{13}$ Carlin et al. (2001), pp. 2ff. document for the case of Austria that between-sector movements accounted for $6.5 \%$ of the total between 1991 and 1996, i.e. 1.1 percentage points out of a total increase of 17.4 percentage points. In this sense, Austria is entirely typical of market economies.

${ }^{14}$ This was especially the case in Austria.

${ }^{15}$ However, employment losses often appear to be widely exaggerated. For instance, the Communist Party of Austria (2003) argues that the number of employed in the Austrian electricity sector since the start of the "liberalization efforts“ has already shrunk from 33 thousands to 22 thousands. If one uses the EU as a benchmark this number will probably be further reduced 16 thousands.

${ }^{16}$ Own calculations based on an econometrically estimated simulation model.

${ }^{17}$ Average price reduction period 1996-2001.

${ }^{18}$ Nowotny 1998, pp. 41 ff., describes the "Austrian experiment" of privatization more deeply, differentiating with respect to the character and form of privatization in terms of change in ownership, change in regulation, corporatization, liberalization to activities promoting efficiency and competition within the government, and change in competition. Privatization does not necessarily imply a withdrawal of the state from economic policy. The government still has to define the conditions for an efficient activity of enterprises and to meet precautionary measures against market failure, namely measures in the area of competition policy and antitrust law as well as in environmental policy. See Nowotny (1998), p. 46.

${ }^{19}$ However, Schaffhauser-Linzatti and Dockner (1999) conclude that there was no significant change between the period of state ownership and privatization with respect to efficiency, leverage, investment behavior and output. Instead, they are able to identify a significant change for profitability and employment. See also Clemenz (1999), p. 21.

${ }^{20}$ See Nowotny (1998), p. 43. Nevertheless, the role of the Vienna stock exchange was still limited until Eastern enlargement of the EU. 
${ }^{21}$ See Clemenz in Austrian Parliament (2000).

${ }^{22}$ Astonishingly and perhaps due to the specific Austrian phenomenon of politically motivated decision making even in business affairs, neither the unions nor the works council of the Bank Austria opposed to the takeover of the Bank Austria by the Bavarian HypoVereinsbank. See EIRO (2002).

${ }^{23}$ See, for instance, Aiginger (1999).

${ }^{24}$ See OeIAG (2003). This should be done by means of syndicates with industrial partners, banks, insurance companies, pension funds, severance pay funds, investment funds, etc. (1998), p. 43, explicitly mentions the Austrian efforts to achieve a domestic owner ship component by means of granting of preferences to employees and of an Austrian bonus in the case of shares hold for a longer time. In 1998, it was estimated that around 50 percent of the shares were still in private Austrian ownership.

${ }^{25}$ This view is also totally consistent with the remarkable change of positions of the Freedom party, which became determined anti-European, after being the sole supporter of Austrian ECmembership for a long time, see Clemenz, 1999, p. 17.

${ }^{26}$ Biais and Perotti (2002) show that privatizing governments that cannot commit to absentism are still able to reduce investors' perceived probability of future interference by allocating underpriced shares to median class voters. Hence, the number of shares of the SOE initially sold and the associated underpricing will increase with the degree of income inequality of the privatizing country.

${ }^{27}$ However, also left-wing governments embark on privatization but mostly when fiscal conditions deteriorate (see, e.g., Italy). See Bortolotti and Pinotti (2003) and Jones et al. (1999). Aussenegg (2000) compares the characteristics and the price behavior of case-by-case privatization initial public offerings and private sector initial public offerings in Poland over the first nine years after the reopening of the Warsaw Stock Exchange in April 1991. He finds evidence that the Polish government is market-oriented, trying to build up reputation for its privatization policy over time by underpricing, selling a high fraction at the initial offer and underpricing more when selling to domestic retail investors.

${ }^{28}$ See Clemenz in Austrian Parliament (2000). As a norm, deadlines should be valid for the setting of concepts, but not for specific privatization projects. However, from a politoeconomic point of view, the latter serves a better de-synchronization with election dates.

${ }^{29}$ Nowotny 1998, p. 38, and Schaffhauser-Linzatti (2003) describe how Austria has reacted to specific EU-directives. A dominant share of liberalization and deregulation took place in Austria with an eye on the obligation to meet EU-standards. This led to an abolishment of state monopolies and the creation of market competition even in cases of alleged natural monopolies and, thus, had appositive impact on the speed of privatization. See Clemenz (1999), p. 17.

${ }^{30}$ This question has already been raised by Aiginger (1997), p. 351, with respect to the very early second privatization wave in Austria in the second half of the eighties and answered as follows: "Sie war durch den Regierungseintritt der ÖVP initiiert und wohl wegen der Budgetengpässe durchsetzbar". Analogously, Jeronimo, Pagan and Soydemir (2000) analyze whether deficits and indebtedness in the 1990s in Spain, Italy, Portugal and Greece were associated with a shift from privatization as a tool of economic restructuring, to privatization as a tool of European monetary convergence. Their empirical results suggest that privatization funds accruing from the sale of state-owned enterprises in the Southern European countries might have been used to tackle budget deficits and meet the stringent debt criterion for monetary integration.

${ }^{31}$ See, among others, Clemenz (1999), p. 1.

${ }^{32}$ However, even under the "New Austrian Public Policies" the EU commitment could not prevent the emergence of a political cycle. Even shortly after the Maastricht Treaty came into force, Austrian government deficits and debt increased systematically for three consecutive years before the general elections of 1994. See, e.g., Clemenz, 1999, p. 4. 


\section{CESifo Working Paper Series}

(for full list see www.cesifo.de)

1057 Carsten Hefeker, Structural Reforms and the Enlargement of Monetary Union, October 2003

1058 Henning Bohn and Charles Stuart, Voting and Nonlinear Taxes in a Stylized Representative Democracy, October 2003

1059 Philippe Choné, David le Blanc and Isabelle Robert-Bobée, Female Labor Supply and Child Care in France, October 2003

1060 V. Anton Muscatelli, Patrizio Tirelli and Carmine Trecroci, Fiscal and Monetary Policy Interactions: Empirical Evidence and Optimal Policy Using a Structural New Keynesian Model, October 2003

1061 Helmuth Cremer and Pierre Pestieau, Wealth Transfer Taxation: A Survey, October 2003

1062 Henning Bohn, Will Social Security and Medicare Remain Viable as the U.S. Population is Aging? An Update, October 2003

1063 James M. Malcomson, Health Service Gatekeepers, October 2003

1064 Jakob von Weizsäcker, The Hayek Pension: An efficient minimum pension to complement the welfare state, October 2003

1065 Joerg Baten, Creating Firms for a New Century: Determinants of Firm Creation around 1900, October 2003

1066 Christian Keuschnigg, Public Policy and Venture Capital Backed Innovation, October 2003

1067 Thomas von Ungern-Sternberg, State Intervention on the Market for Natural Damage Insurance in Europe, October 2003

1068 Mark V. Pauly, Time, Risk, Precommitment, and Adverse Selection in Competitive Insurance Markets, October 2003

1069 Wolfgang Ochel, Decentralising Wage Bargaining in Germany - A Way to Increase Employment?, November 2003

1070 Jay Pil Choi, Patent Pools and Cross-Licensing in the Shadow of Patent Litigation, November 2003

1071 Martin Peitz and Patrick Waelbroeck, Piracy of Digital Products: A Critical Review of the Economics Literature, November 2003 
1072 George Economides, Jim Malley, Apostolis Philippopoulos, and Ulrich Woitek, Electoral Uncertainty, Fiscal Policies \& Growth: Theory and Evidence from Germany, the UK and the US, November 2003

1073 Robert S. Chirinko and Julie Ann Elston, Finance, Control, and Profitability: The Influence of German Banks, November 2003

1074 Wolfgang Eggert and Martin Kolmar, The Taxation of Financial Capital under Asymmetric Information and the Tax-Competition Paradox, November 2003

1075 Amihai Glazer, Vesa Kanniainen, and Panu Poutvaara, Income Taxes, Property Values, and Migration, November 2003

1076 Jonas Agell, Why are Small Firms Different? Managers’ Views, November 2003

1077 Rafael Lalive, Social Interactions in Unemployment, November 2003

1078 Jean Pisani-Ferry, The Surprising French Employment Performance: What Lessons?, November 2003

1079 Josef Falkinger, Attention, Economies, November 2003

1080 Andreas Haufler and Michael Pflüger, Market Structure and the Taxation of International Trade, November 2003

1081 Jonas Agell and Helge Bennmarker, Endogenous Wage Rigidity, November 2003

1082 Fwu-Ranq Chang, On the Elasticities of Harvesting Rules, November 2003

1083 Lars P. Feld and Gebhard Kirchgässner, The Role of Direct Democracy in the European Union, November 2003

1084 Helge Berger, Jakob de Haan and Robert Inklaar, Restructuring the ECB, November 2003

1085 Lorenzo Forni and Raffaela Giordano, Employment in the Public Sector, November 2003

1086 Ann-Sofie Kolm and Birthe Larsen, Wages, Unemployment, and the Underground Economy, November 2003

1087 Lars P. Feld, Gebhard Kirchgässner, and Christoph A. Schaltegger, Decentralized Taxation and the Size of Government: Evidence from Swiss State and Local Governments, November 2003

1088 Arno Riedl and Frans van Winden, Input Versus Output Taxation in an Experimental International Economy, November 2003

1089 Nikolas Müller-Plantenberg, Japan’s Imbalance of Payments, November 2003 
1090 Jan K. Brueckner, Transport Subsidies, System Choice, and Urban Sprawl, November 2003

1091 Herwig Immervoll and Cathal O'Donoghue, Employment Transitions in 13 European Countries. Levels, Distributions and Determining Factors of Net Replacement Rates, November 2003

1092 Nabil I. Al-Najjar, Luca Anderlini \& Leonardo Felli, Undescribable Events, November 2003

1093 Jakob de Haan, Helge Berger and David-Jan Jansen, The End of the Stability and Growth Pact?, December 2003

1094 Christian Keuschnigg and Soren Bo Nielsen, Taxes and Venture Capital Support, December 2003

1095 Josse Delfgaauw and Robert Dur, From Public Monopsony to Competitive Market. More Efficiency but Higher Prices, December 2003

1096 Clemens Fuest and Thomas Hemmelgarn, Corporate Tax Policy, Foreign Firm Ownership and Thin Capitalization, December 2003

1097 Laszlo Goerke, Tax Progressivity and Tax Evasion, December 2003

1098 Luis H. B. Braido, Insurance and Incentives in Sharecropping, December 2003

1099 Josse Delfgaauw and Robert Dur, Signaling and Screening of Workers' Motivation, December 2003

1100 Ilko Naaborg,, Bert Scholtens, Jakob de Haan, Hanneke Bol and Ralph de Haas, How Important are Foreign Banks in the Financial Development of European Transition Countries?, December 2003

1101 Lawrence M. Kahn, Sports League Expansion and Economic Efficiency: Monopoly Can Enhance Consumer Welfare, December 2003

1102 Laszlo Goerke and Wolfgang Eggert, Fiscal Policy, Economic Integration and Unemployment, December 2003

1103 Nzinga Broussard, Ralph Chami and Gregory D. Hess, (Why) Do Self-Employed Parents Have More Children?, December 2003

1104 Christian Schultz, Information, Polarization and Delegation in Democracy, December 2003

1105 Daniel Haile, Abdolkarim Sadrieh and Harrie A. A. Verbon, Self-Serving Dictators and Economic Growth, December 2003

1106 Panu Poutvaara and Tuomas Takalo, Candidate Quality, December 2003 
1107 Peter Friedrich, Joanna Gwiazda and Chang Woon Nam, Development of Local Public Finance in Europe, December 2003

1108 Silke Uebelmesser, Harmonisation of Old-Age Security Within the European Union, December 2003

1109 Stephen Nickell, Employment and Taxes, December 2003

1110 Stephan Sauer and Jan-Egbert Sturm, Using Taylor Rules to Understand ECB Monetary Policy, December 2003

1111 Sascha O. Becker and Mathias Hoffmann, Intra-and International Risk-Sharing in the Short Run and the Long Run, December 2003

1112 George W. Evans and Seppo Honkapohja, The E-Correspondence Principle, January 2004

1113 Volker Nitsch, Have a Break, Have a ... National Currency: When Do Monetary Unions Fall Apart?, January 2004

1114 Panu Poutvaara, Educating Europe, January 2004

1115 Torsten Persson, Gerard Roland, and Guido Tabellini, How Do Electoral Rules Shape Party Structures, Government Coalitions, and Economic Policies? January 2004

1116 Florian Baumann, Volker Meier, and Martin Werding, Transferable Ageing Provisions in Individual Health Insurance Contracts, January 2004

1117 Gianmarco I.P. Ottaviano and Giovanni Peri, The Economic Value of Cultural Diversity: Evidence from US Cities, January 2004

1118 Thorvaldur Gylfason, Monetary and Fiscal Management, Finance, and Growth, January 2004

1119 Hans Degryse and Steven Ongena, The Impact of Competition on Bank Orientation and Specialization, January 2004

1120 Piotr Wdowinski, Determinants of Country Beta Risk in Poland, January 2004

1121 Margarita Katsimi and Thomas Moutos, Inequality and Redistribution via the Public Provision of Private Goods, January 2004

1122 Martin Peitz and Patrick Waelbroeck, The Effect of Internet Piracy on CD Sales: CrossSection Evidence, January 2004

1123 Ansgar Belke and Friedrich Schneider, Privatization in Austria: Some Theoretical Reasons and First Results About the Privatization Proceeds, January 2004 